CAHIER DE RECHERCHE \#2105E

Département de science économique

Faculté des sciences sociales

Université d'Ottawa
WORKING PAPER \#2105E

Department of Economics

Faculty of Social Sciences

University of Ottawa

\title{
World War II, the Baby Boom and Employment: County Level Evidence*
}

\author{
Abel Brodeur and Lamis Kattan ${ }^{\dagger}$
}

April 2021

\footnotetext{
* We thank Siwan Anderson, Andriana Bellou, Matthias Doepke, Raquel Fernandez, Jason Garred, Adam Lavecchia, Louis-Philippe Morin, Sahar Parsa, Lucienne Talba and Matt Webb, and seminar participants at the Alex Trebek Forum for Dialogue, CEA annual conference, SOLE/EALE conference and University of Ottawa for comments and suggestions. We are grateful to Shannon L. Middleton at the Center for Women Veterans, Department of Veterans Affairs, for help with many questions on VA's women health services. Any remaining errors are our own.

${ }^{\dagger}$ Brodeur: University of Ottawa and IZA. E-mail: abrodeur@uottawa.ca. Kattan: University of Ottawa. Social Sciences Building, 120 University Private, Ottawa, ON K1N 6N5.
} 


\section{Abstract}

This paper examines the impact of male casualties due to World War II on fertility and female employment in the United States. We rely on the number of casualties at the county-level and use a difference-indifferences strategy. While most counties in the U.S. experienced a Baby Boom following the war, we find that the increase in fertility was lower in high-casualty rate counties than in low-casualty rate counties. Analyzing the channels through which male casualties could have decreased fertility, we provide evidence that county male casualties are positively related to 1950s female employment and household income.

Key words: Baby Boom, Fertility, Female Labor Supply, World War II. JEL Classification: J11, J13, J24, N3, N4. 
In today's America, the typical woman has one or two children, is engaged in paid work and enjoys the same legal rights as men. This has not always been the case. At the end of the 19th century, approximately 5 percent of married white women were engaged in paid work and the total fertility rate was about 3.5 (Goldin (1991); Guinnane (2011)). The decrease in fertility and the increase in female labor supply was not steady and may have been shocked by specific events. For instance, fertility rates declined from 1850 to 1930 and stabilized for several years. This stabilization was followed by exceptionally high birth rates from 1944 to 1961-the Baby Boom- and then a baby bust (Figure 1). ${ }^{1}$

A vast literature documents historical shocks that could have led to female economic empowerment in the 20th century (Fernández et al. (2004); Fernández (2013); Fernández and Wong (2014a,b); Goldin (2006); Goldin and Katz (2002); Guinnane (2011)). In this study, we reassess the role of one of these potential shocks, World War II (WWII). During WWII, about 16 million men were mobilized and deployed in Asia and Europe, which coincided with a sharp rise in female employment. At the height of the war, women comprised approximately 35 percent of the civilian labor force (Acemoglu et al. (2004)).

Goldin and Olivetti (2013), Acemoglu et al. (2004) and Doepke et al. (2015) rely on mobilization rates to identify the long run impact of the war on female labor force participation, the wage structure and fertility, respectively. Mobilization rates vary across states because of many factors (e.g., dependents, occupation and fitness to serve) that led to deferments. Using this variation, Goldin and Olivetti (2013) provide evidence that women's labor supply was shifted during the war and that the effect persisted for some of the women who worked in white-collar positions during WWII. Similarly, Acemoglu et al. (2004) provide evidence that women worked more in 1950 in states with a higher mobilization rate and that this increase in female labor supply lowered female and male wages. Doepke et al. (2015) find that states with a greater mobilization of men experienced a larger post-war increase in fertility. They argue that the return of men from the war crowded out younger women leading them to opt for marriage and childbearing.

Our purpose is to reexamine the effect of WWII on fertility and women's employment. We first investigate the reproducibility of the results described above. We then complement these studies by relying on novel data on male casualties at a more disaggregated level (i.e., county). Last, we

\footnotetext{
${ }^{1}$ The increase in the female labor force participation was steady between 1930 to 1970 .
} 
investigate some of the mechanisms through which WWII casualties may have affected fertility, focusing on the labor and marriage markets.

We begin with a replication of Doepke et al. (2015)'s analyses using a similar empirical model. We successfully replicate their main results and show that state casualty and mobilization rates are positively correlated to fertility post-WWII. One concern with their results is that socioeconomic factors causing differences in male casualties or mobilization could also affect post-war fertility. One key variable is race as the U.S. Army was still segregated when the U.S. entered WWII. Figure 2 illustrates the geographic distribution of the casualty rates both across-states and withinstates, across-counties. This figure shows that the Deep South overwhelmingly consisted of low-casualty rate counties, partly due to the U.S. military segregation. $^{2}$

We thus enrich Doepke et al. (2015)'s main specification with the share of black men and additional control variables such as the share of fathers and average educational attainment. Once we control for these additional pre-war characteristics, the point estimates become negative, suggesting that higher male causalities and mobilization rates led to lower fertility post-WWII. This sensitivity analysis sheds light on the importance to further control for key determinants of male mobilization (or casualty) and fertility, and taking into account regional trends in fertility. ${ }^{3}$

We then turn to our novel county-level analysis. Our empirical strategy consists of comparing counties with high and low casualty rates, before and after the war. Analyzing the effect of WWII on fertility at the county-level brings the analysis to a more disaggregated level. This has a key advantage over the state-level analysis since counties across states may have very different demographic and socioeconomic characteristics. Additionally, one of the main sources of potential bias in cross-state regressions likely stems from important regional trends in fertility. Relying on the county-level data allows us to account for these trends by controlling for all time-varying state characteristics and solely relying on the within-state variation. Countylevel data thus strengthens the credibility of the identification strategy.

While most counties in the U.S. experienced a Baby Boom following the war, we find that the increase in fertility was lower in high-casualty

\footnotetext{
${ }^{2}$ When black men volunteered for duty or were drafted following the Pearl Harbor attack, they were relegated to segregated divisions and combat support roles, such as cook, quartermaster and grave-digging duty (Bristol and Stur (2002)).

${ }^{3}$ Appendix Figure A1 shows that the U.S. South, in particular, had a unique fertility trajectory. In the late 1940s, the gap between the South and other regions starts to close, suggesting that regions with relatively higher casualty rate had a relatively lower decrease in fertility.
} 
rate counties than in low-casualty rate counties in 1950. Our estimates are statistically significant and suggest that women had, on average, about $15 \%$ fewer babies in a county that had a one percentage point higher casualty rate during WWII. We show that the sign of the county-level estimates is robust to the inclusion of pre-war county determinants of WWII casualties, as well as a set of extended controls that might have potentially affected fertility levels. We also show that our findings are robust to the exclusion of states with a large share of black residents or large post-war net migration. Of note, we find weak evidence that WWII casualties affect fertility rates in 1960 and no evidence that the war casualties impacted fertility in 1970 .

In order to gain insight on the mechanisms through which WWII casualties may have decreased fertility, we follow the literature and test the effect of male casualties on female employment and other socioeconomic outcomes. We reexamine the effect of WWII on female employment at the State Economic Area (SEA) level. A SEA is either a single county or a group of counties. Our results are in line with those of Acemoglu et al. (2004) and Goldin and Olivetti (2013) as we find that SEA-level casualty rates during WWII led to a shift in female employment in 1950. Our findings also suggest that greater casualties reduced individual wages (Acemoglu et al. (2004)), but that the increase in after-war household income was higher in high casualty rate SEAs than in low casualty rate SEAs.

This set of results suggests an explanation consistent with Becker's theory of fertility (Becker (1960); Becker and Lewis (1973); Becker and Barro (1989)). Becker argued that parents derive utility from both the number and the quality of children. When their earnings increase, parents tend to be more likely to invest in their children's human capital and decrease the number of children they have. We provide empirical evidence supporting this theory by relying on infant mortality data and computing the percentage of live births attended by physicians at the hospital. We find that county male casualties are positively associated to the percentage of attended births by physicians at the hospital and negatively related to infant mortality in the after-war period, indicating better health outcomes for newborn kids. These results provide suggestive evidence that parents in high casualty rate counties invest more in the quality of their children during pregnancy and after birth. ${ }^{4}$

Another important channel through which male casualties could have

\footnotetext{
${ }^{4}$ See Doepke et al. (2015) for a detailed account of the work of Becker on the quantity and quality of children. Becker provides many examples of child quality choices such as giving them dance and music lessons and sending them to private colleges.
} 
impacted fertility is male-to-female sex ratios and the marriage market. A recent study by Brainerd (2017) shows that the drastic change in sex ratios caused by World War II in Russia led to lower rates of marriage and fertility and higher non-marital births, and reduced the bargaining power within marriage for women in areas most affected by war casualties. ${ }^{5}$ Our fertility results are in line with Brainerd (2017), but we find no evidence that WWII casualties decreased marriage rates. This could be due to the relatively small decrease in sex ratios for most U.S. counties (i.e., roughly $1 \%$ ), compared to a decrease of about $28 \%$ in Russia. We also show that WWII casualties led to a significant increase in the age of having a first child for young women aged between 15 and 25 years old in 1950, which can explain the decrease in fertility especially for women in this age category.

Overall, our analysis of the effect of WWII casualties on socioeconomic outcomes provide plausible explanations for the negative relationship between male casualties and fertility in 1950. The absence of men during and after WWII led to an increase in women's employment during and after the war, which increased household income. The combined effects of these two phenomena slowed down the Baby Boom in counties with relatively more casualties. Our findings thus suggest that there was a strong link between young women's labor market and fertility in the baby boom period, and that the labor market was affected strongly by the war (Acemoglu et al. (2004); Doepke et al. (2015)).

Our study contributes to a large literature providing socioeconomic explanations to the Baby Boom. ${ }^{6}$ Previous studies have emphasized the role of parents (Rutherdale (1999)), technological progress in the household sector (Greenwood et al. (2005)) ${ }^{7}$, the Great Depression (Bellou and Cardia (2014)) and ideological and cultural changes (Lesthaeghe and Surkyn (1988)). Albanesi and Olivetti (2014) also provide evidence that improvements in maternal health contributed to the Baby Boom in the U.S. Using cross-state variation, they show that the decline in maternal mortality is associated with a rise in fertility for women born in the 1920-30s. Our

\footnotetext{
${ }^{5}$ Abramitzky et al. (2011) evaluate the impact of war on assortative matching in the marriage market and find that World War I has led to a decrease in the probability of marriage for women in French regions with higher mortality rates.

${ }^{6}$ One of the most well-known explanations for the Baby Boom is the "catch-up fertility" hypothesis (Easterlin (1961)). This theory, based on the concept of "relative income," states that people who grew up during the Great Depression had low material well-being and increased their demand for children during the post-WWII economic expansion (Jones and Schoonbroodt (2016)).

${ }^{7}$ Bailey and Collins (2011) provide empirical evidence that the Amish experienced a Baby Boom and that appliance ownership and electrification are negatively correlated to changes in fertility rate.
} 
county-level analysis allows us to control for this type of time-varying statelevel shocks.

Our paper also contributes to a literature that analyzes the effect of war on fertility and female labor supply (Bellou and Cardia (2016); Bethmann and Kvasnicka (2013); Eder (2016); Boehnke and Gay (2017); Jaworski (2014); Vandenbroucke (2014)) and to a vast literature on sex ratios and the marriage market (Carranza (2014); Grosjean and Khattar (2019); Lafortune (2013); Qian (2008)).

We structure the remainder of the paper as follows. In section 1, we present the data sources and descriptive statistics. Section 2 presents the methodology. Section 3 replicates the results of Doepke et al. (2015) at the state-level. In section 4, we provide the regression results for fertility at the county-level and a large set of robustness checks. In the subsequent section, we empirically examine the channels, and the last section concludes.

\section{Data}

\subsection{World War II Casualties}

During the war, 16 million Americans served in the United States Armed Forces, of whom over 400,000 did not return home. Besides its random component, the variation of male casualties across different counties is affected by the occurrence of draft deferrals. The United States Armed Forces consisted largely of "Citizen Soldiers" drawn from civilian life. The majority, roughly 10 million, joined the military through the draft, and most draftees were assigned to the army. However, the Selective Service granted deferments based on specific factors such as marital status, fatherhood, combat skills including the ability to serve, and medical disabilities. Mobilization rates for fathers were low as they were generally drafted last in the local draft pool. Furthermore, deferments were offered based on occupation. One of the main determinants of draft deferments was farmer status as farming was needed to maintain the level of food supply during the war. Note that most deferments were eliminated during the war. For example, both the wife and child deferment ended in 1943 (Goldin and Olivetti (2013)).

We rely on monographs from the National Archives to construct our measure of military casualties at the county-level. The dataset is compiled by the Department of the Navy and Bureau of Naval Personnel using The Honor List of Dead and Missing for each state in the United States, published by the War Department. This list contains the most complete data available on all military personnel who were killed up until January 31, 
1946. Errors in this list were minimized by careful checks by the Casualty Branch of The Adjutant General's Office and by Machine Records Units. Note that civilian casualties are not included in these reports.

We construct casualty rates at the county-level as the number of men killed in action during WWII, divided by the number of men between the ages of 18 and 44 in 1940, and multiplied by 100. Census data on male population in 1940 per age category is retrieved from the National Historical Geographic Information System (NHGIS). Note that the 1940 Selective Service and Training Act required that men between the ages of 21 and 35 register to the draft. Registration was extended a few times during the war, including a new Service Act which made men between 18 and 45 liable for military service. By the end of the war in 1945, 50 million men between 18 and 45 had registered for the draft and 10 million had been inducted in the military. We thus rely on the male population of this age group as a proxy for the number of registered men (Acemoglu et al. (2004)).

\subsection{Fertility and Socioeconomic Characteristics}

Our analysis uses fertility and socioeconomic characteristics of women and children before and after WWII as the primary outcomes of interest. Data on fertility is from the 1915-2007 U.S. County-Level Natality and Mortality Data (Bailey et al. (2016)), retrieved from ICPSR. We rely on the number of total live birth by place of occurrence between 1933 and 1972. Note that data on births by place of occurrence begins to be complete in the dataset starting 1933. Additionally, total births at the county-level are available for the years 1915-1941 from Vital Statistics: Natality \& Mortality Data. For the female population, we only consider women of childbearing age (i.e., between 15 and 44 years old) for the years 1915-1972 also from Vital Statistics: Natality \& Mortality Data. ${ }^{8}$

For data on the number of children, labor supply, age of first time mothers, personal earnings, and other individual characteristics, we rely on Census data from the $1 \%$ Integrated Public Use Microdata Series (IPUMS) of the 1940 and 1950 censuses (Ruggles et al. (2010)). Unfortunately, this dataset is not available at the county-level for 1950. We thus rely on data at the SEA-level for this analysis. SEA stands for State Economic Area (see

\footnotetext{
${ }^{8}$ Total births and population data are from the Census Bureau's vital statistics annual reports for states (including territories) and counties. Births are limited in geographic extent to the Birth Registration Areas established in each year. Michael Haines at Colgate University provided NHGIS with the source data, which were entered from printed census publications, and NHGIS researchers organized the data into tables and assigned meta-data on topics, categories, etc.
} 
Bogue (1951) for more details). An SEA is either a single county or a group of counties within the same state that have similar economic characteristics. Importantly, the definitions of SEAs in 1940 and 1950 are similar. The age of a first time mother is computed by subtracting the age of the eldest child from the age of the mother. To measure labor supply, we use a dummy that indicates whether a woman is currently employed, and the total number of weeks worked per year. Personal earnings are considered for employed men and women, and are deflated by the $1990 \mathrm{CPI}$.

To examine the impact of WWII casualties on infants' health, we rely on the percentage of live births attended by physicians at hospital and infant mortality measured as the death of young children under the age of one. County-level data on births by attendant by place of residence is available between 1939 and 1959 from NHGIS, derived from annual reports of vital statistics for states (including territories) and counties from the U.S. Census Bureau (1939-1944) and the U.S. Public Health Service (1945-1959). For infant mortality, data is available by place of occurrence from 1915 to 1941, and from 1959 to 1972 originally from Vital Statistics: Natality \& Mortality Data. $^{9}$

\subsection{Descriptive Statistics}

Table 1 displays summary statistics for WWII casualties, fertility and female population by decade for 1940-1970. The average number of casualties by county is about 99 . The standard deviation is remarkably large (422) at the county-level. As mentioned previously, the casualty rate is the fraction of registered men who were killed during World War II. The casualty rate is roughly 1 percent and the standard deviation is 0.39 . We split the sample into low-casualty and high-casualty counties using the casualty rate mean. There are a total of 3,070 counties, 1,639 of which are in the low casualty rate category. The mean casualty rate for low- and high- casualty rate counties is 0.78 and 1.26 percent, respectively.

The average number of total live births per county increased by approximately 50\% between 1940 and 1950, illustrating the Baby Boom period. This increase occurred in both high and low casualty rate counties, although the increase was larger in low casualty rate counties for 1950 and 1960.

\footnotetext{
${ }^{9}$ The 1959-1967 data are derived from printed annual reports from the U.S. Public Health Service. The 1968-1972 data are derived from individual-level microdata (either birth certificates or the Compressed Mortality File) from the National Center for Health Statistics.
} 
Appendix Table A1 reports means and standard deviations for the individual characteristics of interest at the SEA-level. The average age of mothers at the time of first birth, women's employment rate and weekly wages all increased after the war. Of note, women's employment rate increased from $25 \%$ in 1940 to $31 \%$ in 1950 . This increase was larger in high casualty rate counties.

\section{Identification Strategy}

In this section, we first show that casualty and mobilization rates are highly correlated. We then discuss the identification assumption and describe the main specification

\subsection{State Casualty and Mobilization Rates}

Male mobilization during the war might be seen as the best source of exogenous variation across states or counties. ${ }^{10}$ However, to the best of our knowledge, data on male mobilization at the county-level is unavailable. Instead, we rely on male casualties as a measure of WWII intensity for our county-level exercise. Our analysis thus differs from Acemoglu et al. (2004), Doepke et al. (2015) and Goldin and Olivetti (2013) along two dimensions. First, we rely on novel county-level data instead of state-level data. This means that we are exploiting within-state across-county variation instead of across-state variation. Second, our identifying variation comes from casualty rates instead of mobilization rates. We provide empirical evidence throughout that the latter dimension does not drive our main conclusions.

Figure 3 illustrates that differences in casualty rates mostly reflect differences in mobilization rates. This figure plots both state mobilization and casualty rates. Male casualties are positively and highly correlated with male mobilization at the state-level. The correlation coefficient between mobilization and casualty rates is $0.55 .^{11}$

\footnotetext{
${ }^{10}$ According to the National WWII Museum, $61.2 \%$ of the military were drafted, while only $38.8 \%$ were volunteers.

${ }^{11}$ New Mexico faced the highest rate of casualties, exceeding 350 per 100,000 people during WWII, and possibly represents an outlier. Excluding New Mexico makes the positive relationship between male mobilization and casualties stronger, with a correlation coefficient of 0.62 (see Figure 3, second panel). Excluding New Mexico from the analysis has no effect on our conclusions. Results available upon request.
} 


\subsection{Identification Assumption}

This paper relies on the parallel trends assumption that in the absence of male war casualties, the average change in birth rates would have not been systematically different between counties with low- and high-casualty rates. This identification assumption could be violated if the casualty rate is related to pre-war demographic and socioeconomic characteristics of counties. We argue in what follows that our results are not driven by pre-war factors.

As shown in Table 1, the number of casualties was not uniform across counties. As with mobilization rates, the variation in the cross-county casualty rates could arise from observable economic factors in addition to the random component. Our concern is that socioeconomic factors causing differences in male casualties also affect our outcome variables.

Race The United States military was still segregated during World War II. Even though mobilized men were randomly drafted from the registered pool, less than 4,000 African-Americans were serving in the military and only 12 African-Americans were officers in 1941. In fact, during the war period, the segregation practices of civilian life spilled over into the military. Pressures from the National Association for the Advancement of Colored People led President Roosevelt to pledge that African-Americans would be enlisted according to their percentage in the population. ${ }^{12}$ Although this percentage was never actually met during the war, the number of AfricanAmericans in the army grew drastically. Of note, though, blacks were often classified in separate units for combat and were not allowed to fight on the front lines. They were mostly given support duties and were not allowed to be in units with white soldiers. A total of 1.2 million African Americans served in the U.S. Armed Forces in segregated divisions and 708 were killed in action. ${ }^{13}$ Below, we show that our main findings are robust to excluding states with a high black population from the analysis.

Education In addition to fitness, the selection of men to serve in the army may have been related to education. Between June and July 1943, $8 \%$ of white troops rejected and $34.5 \%$ of African-American troops rejected were for educational deficiencies (Jenkins et al. (1944)). Men were tested and

\footnotetext{
${ }^{12}$ It was not until 1948 that President Harry S. Truman ordered a desegregation of the Armed Services and equality of treatment and opportunity in the U.S. military without regard to race, color, religion or national origin.

${ }^{13} \mathrm{By}$ the end of war, it became more acceptable to have integrated units of both black and white soldiers fighting side by side on the front line in order to maintain the strength of the military (see Sandler (1992) and Wynn (1993)).
} 
sent to units based on their educational backgrounds. For instance, servicemen in the infantry branch were less educated as the infantry required a lower logistical burden. Infantry soldiers (also known as foot soldiers) operated under the worst conditions and performed missions that were not assigned to any other units. Even though the infantry branch faced the highest number of casualties, it constituted only $6 \%$ of the entire units. Additionally, Appendix Figure A2 shows a weak positive correlation between casualty rates and the county's average years of education for men between 18 and 44 years old in 1940 .

Economic Conditions One of the main reasons for deferment was farm occupation in order to maintain the food supply during the WWII period. Acemoglu et al. (2004) show that there is a negative correlation between male mobilization and a state's percentage of farmers. With male farmers being deferred, we would expect fewer casualties in rural counties. Additionally, deferments of drafted men could potentially be affected by their economic conditions. Wealthy and connected men could avoid being mobilized or get assigned to non-combat roles. For example, poor men who did not have a record of private medical care may find it harder to obtain medical deferments. However, Appendix Figure A3 shows that the casualty rate and the county's average wage income of men aged between 18 and 44 in 1940 are very weakly correlated.

As a robustness check, we will include the covariates identified by Acemoglu et al. (2004) to our baseline model to account for correlates of differences in casualty rates by county that may affect our main outcome. Our results are robust to including 1940 county specific characteristics (such as fathers share, black population share, and average years of education) interacted with the after war year dummies, which suggests that our identification assumption is credible. Additionally, we include county fixed effects in the empirical analysis to control for any county specific time-invariant characteristics that may affect fertility.

\subsection{Model Specification}

Our hypothesis is that the increase in fertility during the Baby Boom period was lower in counties where World War II casualty rates were high. To investigate this hypothesis, we estimate the following specification:

$$
y_{c t}=\lambda_{c}+\delta d_{w a r}+\mu d_{w a r} \times R_{c}+X_{c t}^{\prime} \omega+\varepsilon_{c t}
$$


where $y_{c t}$ is the natural log of total live births or birth rates in county $c$ and year $t$. We include a full set of county dummies $\lambda_{c}$ to control for timeinvariant county characteristics. The variable $d_{\text {war }}$ equals one for after-war years and zero for the pre-war period. The after war dummy takes the value of zero for 1940 and one for the years 1950, 1960, and 1970 in different regressions, each of which includes data for 1940 and one of these years. This allows us to investigate the short run and the long run effects of war casualties on fertility. The variable $R_{c}$ is the casualty rate by county. In the binary regressions, it takes the value of one if the county belongs to the high casualty rate category and zero if the county is in the low casualty rate category. In the continuous regressions, this variable is defined as continuous to estimate the impact of a percentage point increase in the casualty rate on fertility. The interaction of $d_{w a r}$ and $R_{c}$ shows the effect of the treatment. The coefficient of interest here is thus $\mu$. We cluster standard errors at the county-level.

$X_{c t}$ is a vector of covariates including the natural log of female population of childbearing age (i.e., between 15 and 44 years old). Using the general fertility rate computed as the number of live births by 100 women as the dependent variable yields similar findings (see section 4).

In section 3, we rely on the state-level variation of these variables in order to reconcile our county-level findings with previous studies at the state level.

As a robustness check, we include state-decade fixed effects to relax the identification assumption. The inclusion of state-decade fixed effects in the model allows us to control for time-varying state policies and shocks such as cross-state variation in pregnancy-related mortality (Albanesi and Olivetti (2014)).

In a set of robustness checks, we control for pre-war county's demographic and socioeconomic characteristics. This is an important specification check since these factors may have caused differences in casualties and fertility and thus lead to a bias in our estimates. More precisely, we interact the "After War" dummy with the following socioeconomic characteristics to allow them to differ by decade: the share of male farmers between the ages of 18 and 44, the share of black men between the ages of 18 and 44, the share of fathers between the ages of 18 and 44 and the average years of education for men between the ages of 18 and 44. We also control for county-level lagged changes between census years 1930-1940 (interacted with the "After War" dummy) in economic or demographic variables that could affect fertility such as Age at First Marriage (for married women 
only), Dwelling Ownership (share of those who own a dwelling out of total population for both men and women above the age of 16), and Female Labor Force Participation (for women aged between 16 and 64).

\section{State-Level Results}

Before turning our attention to our novel county-level male casualty data, we first replicate the results of Doepke et al. (2015) at the state-level. This exercise serves at least two purposes. First, we believe reproducibility is a key part of the scientific method, and that replications may help to improve our understanding of previous research findings. Second, this exercise may shed some light on the key differences between our state and county analyses.

We first replicate the findings of Doepke et al. (2015) using a similar specification. We then explore the robustness of their results to additional control variables. Our replicated results are presented in Table 2, which contains OLS estimates of equation 1 at the state-level. In their analysis, Doepke et al. (2015) rely on pooled census data from 1940 and 1960 and restrict the sample to women aged between 25 and 35 years old. ${ }^{14}$ Their main dependent variables are "Children under age of 5" and "Children ever born". For our replication, we rely on the number of children under the age of 5 (columns 1-4) from the pooled micro data from the 1940 and 1960 censuses and complement this analysis using data on the number of total live births (columns 5-8) from Vital Statistics. In the top panel, we rely on the casualty rate, while the bottom panel shows estimates for the mobilization rate. Columns 1, 2, 5 and 6 present estimates for the binary regressions, in which the casualty (or mobilization) rate variable is a dummy that takes the value of one for high-casualty (or mobilization) rate states and zero for low-casualty (or mobilization) rate states. Columns 3, 4, 7 and 8 show estimates for the continuous regressions, in which casualty (or mobilization) rate is a continuous variable.

We successfully replicate the state-level results in Doepke et al. (2015) using both mobilization and casualty rates. In columns 1 and 3, we find that state casualty and mobilization rates are positively correlated with the number of children under the age of 5 for women aged between 25 and 35 years old. The point estimates are strikingly similar in the binary form regressions but differ in magnitude in the continuous form ones. The

\footnotetext{
${ }^{14}$ The authors distinguish between two age groups, women aged 25 to 35 defined as "young" and women aged 45 to 55 defined as "old". We focus on the younger group of women on which the effect of WWII mobilized men is documented.
} 
large difference in magnitudes is due to differences in means as the mean for the casualty rate is around 1\%, while the mean for the mobilization rate is around 45\%. For instance, Beta coefficients suggest that a one standard deviation increase in casualty rates leads to an increase of 0.03 standard deviation in total births, while a one standard deviation increase in mobilization rates is associated with a 0.04 standard deviation in births (column 3).

We confirm these results from Census data by relying on total births count from Vital Statistics data. In columns 5 and 7, the point estimates for the binary form regressions are positive and statistically insignificant (and of similar magnitude) for both mobilization and casualty rates. The point estimates for the continuous form are also positive, but significant only for mobilization. Overall, these results suggest that Doepke et al. (2015)'s main results are reproducible and that relying on casualty rather than mobilization leads to similar conclusions.

To further examine the reproducibility of Doepke et al. (2015)'s conclusions, we add pre-war state demographic and socioeconomic characteristics to the model. More precisely, we add a set of controls to account for state characteristics that may have caused differences in casualties and mobilization: the share of male farmers between the ages of 18 and 44, the share of black men between the ages of 18 and 44, the share of fathers between the ages of 18 and 44 and the average years of education for men between the ages of 18 and 44. All controls are interacted with the "After War" dummy to allow them to differ by decade. The point estimates are presented in columns 2, 4, 6 and 8. We also conduct validation tests for unobservable selection and coefficient stability in columns 2, 4, 6, and 8 following Oster (2019)'s methodology. ${ }^{15}$

Conditional on these controls, the estimates at the state-level for casualty and mobilization rates become negative, suggesting an omitted variable bias in the state-level estimates. In other words, the estimates for the binary and continuous form regressions for both mobilization and casualty rates have a negative sign once we control for selected pre-war state characteristics. Among the included pre-war characteristics, the share of black men is the key variable causing the switch in sign.

These findings provide a major motivation to the use of a finer geographic level for analyzing the impact of WWII casualty on fertility since

\footnotetext{
${ }^{15}$ Oster (2019) argues that $|\delta|>1$ leaves a limited scope for unobservables to explain the results. Our reported parameter $\delta$ thus suggests that the controlled variables are important counfounders to the relationship between missing men and fertility.
} 
states may be composed of counties with very different socioeconomic characteristics and with different casualty and fertility rates. In section 4, we show that the sign of our county-level estimates is robust to the inclusion of a large set of pre-war county characteristics, as well as state-decade dummies.

To sum up, we successfully replicate Doepke et al. (2015)'s fertility results using similar specifications, but provide evidence that the estimates are not robust to the inclusion of key pre-war state characteristics. We argue that relying on county-level data strengthens the credibility of the analysis as it provides the possibility to further control for other (potentially) important state-shocks and state-decade fixed effects. Of note, we have shown that the choice of data source (vital statistics versus pooled Census data) and treatment measure for the intensity of war (mobilization versus casualty rate) does not affect our state-level conclusions.

\section{County-Level Results}

In this section, we estimate the treatment effect of war on fertility by using male casualty rates as a measure of war intensity. Our analysis is now at the county-level and our model includes county fixed effects.

\subsection{Impacts on Fertility}

Table 3 contains OLS estimates of equation 1. The dependent variable is the natural log of total live births. We cluster standard errors at the countylevel. We include county fixed effects and control for the female population in all the regressions. Columns 1, 3 and 5 present estimates for the binary regressions, in which the casualty rate variable is a dummy that takes the value of one for high-casualty rate counties and zero for low-casualty rate counties. Columns 2, 4 and 6 show estimates for the continuous regressions, in which casualty rate is a continuous variable.

What clearly emerges is that county casualty rates are negatively associated with total live births in 1950. Columns 1 and 2 show the estimates for the years 1940-1950. Results indicate that there was a large and highly significant difference in the fertility change between high- and low- casualty rate counties over this time period. The estimate in the binary regression is negative and statistically significant at the 1\% level, suggesting that highcasualty rate counties had significantly fewer total live births compared to counties with lower casualty rates. Interestingly, the increase in the total live birth in 1950 seems to be offset by WWII casualties in the high ca- 
sualty rate counties. In the continuous regression, the point estimate of -0.166 (standard error of 0.04) implies that a one percentage point increase in the male casualty rate during World War II leads to a $15.3 \%$ decrease in fertility.

Columns 3 and 4 show comparable estimates for the years 1940-1960. There is weak evidence that WWII casualties affected total live births in 1960. While the coefficient of the binary regression becomes statistically insignificant, the estimate in the continuous regression shows a persistent effect of male war casualties. Columns 5 and 6 suggest that WWII casualties did not affect fertility rates in 1970 . The estimates are statistically insignificant and smaller in magnitude than for columns 1-4. This result is not surprising as many women of childbearing age (in 1970) were born after WWII.

To observe how the gaps in fertility have been opening and closing during the pre- and post-war period, we rely on yearly county-level data on births by place of occurrence from 1933 to 1972. We illustrate our results by plotting the estimated coefficients from the continuous regression on the natural $\log$ of total live births in Figure 4. We omit the year before the entry of the U.S. into WWII, i.e., 1940 is the reference year. We confirm the pre-treatment trends in the period between 1935 and 1939 and a temporary negative effect of war male casualties on total live births during the 1950s and 1960s, with the impact completely fading away during the early 1970s. Of note, the negative effect starts as early as 1941, when the U.S. was not at war. This result is consistent with increased mobilization activity at the time, even in 1940-1941 in advance of U.S. entry into the war. According to the US Army Center of Military History, mobilization evolved from its gradual beginnings in 1940, speeding up in 1941, expanding dramatically in 1942, and reaching its peak in production in 1943. With the German invasion of Poland in September 1939, President Roosevelt proclaimed a limited national emergency and authorized an increase to 227,000 for the Regular Army and to 235,000 for the National Guard. Thus, a sizeable number of men were employed in the army before the U.S. officially entered the war in December 1941.

We check in Table 4 whether our findings are driven by time-varying changes at the state-level. Our analysis relies on within-state across-county variation because we control for state-decade fixed effects in our model. The inclusion of state-decade fixed effects has no effect on our main conclusions. Our estimates remain negative and statistically significant, although smaller in magnitude. 
In Appendix Table A2, columns 1-2, we test the parallel trend assumption by looking for pre-trends. This assumption requires that in the absence of WWII casualties, the difference between high and low casualty rate counties has a constant trend over time. Unfortunately, county data on total live births are not available for 1930. We instead have to rely on total births. Our pre-war estimates indicate that there was no significant relationship between the change in total births from 1930 to 1940 and county casualty rates during WWII. The estimates for both the binary and continuous regressions are very small and statistically insignificant at conventional levels.

So far, our results provide suggestive evidence that war casualties had a negative effect on fertility. In other words, male casualties during WWII may have slowed down the rise of fertility for counties with many war casualties. We check the robustness of our results in the next subsection.

\subsection{Robustness Checks}

In a first set of robustness checks, we examine the endogeneity of our main independent variable by regressing the natural log of total live births in 1940 on the casualty rate at the county-level. Appendix Figure A4 shows that the regression coefficient is equal to zero, suggesting that casualty rates do not explain the pre-war levels of total live births across counties.

In another set of specification checks, we replicate our analysis of Table 3 , but controlling for pre-war county demographic and socioeconomic characteristics, in Appendix Table A3. As mentioned in Section 2, we interact the "After War" dummy with socioeconomic characteristics to allow them to differ by decade. We also control for county-level lagged economic and demographic changes between census years 1930-1940 (interacted with the "After War" dummy). ${ }^{16}$ Moreover, due to the endogeneity of the farmers' share, we drop counties with higher than $80 \%$ share of male farmers (aged between 18 and 44) in 1940. Our point estimates for 1950 and 1960 are smaller in magnitude, but remain statistically significant at conventional levels. In contrast, our point estimates for 1970 are now larger and significant for the continuous regression. ${ }^{17}$

In Appendix Table A5, we add the set of covariates to the specification including state-decade fixed effects. The point estimates are similar to

\footnotetext{
${ }^{16}$ The inclusion of the extended set of controls in the state-level analysis of Table 2 does not affect our findings. See Appendix Table A4.

${ }^{17}$ While the reported Oster (2019) test highlights the potential importance of unobserved confounders in the baseline models, the additional covariates have limited influence on the estimates as the pattern of our findings remains unchanged.
} 
Table 4 and Appendix Table A3, suggesting that the inclusion of state trends or demographic characteristics equally affect the magnitude of our estimates.

We also check whether the negative relationship between fertility and WWII casualties is driven by less populous counties. To rule out this idea, we split the sample by the median share of counties' population in 1940 relative to the state's population to which they belong in Appendix Table A6. The estimates for the binary (continuous) regressions are larger (smaller) in magnitude in less populous counties in 1950 and 1960. As as additional exercise, we also weight counties by this population share in Appendix Table A7. ${ }^{18}$ The estimates remain negative and significant. The estimates for the binary regressions are smaller in magnitude for 1950 and 1960, while the estimates for the continuous regressions are larger than in our baseline.

We also show that the negative effect of WWII casualties on births occurred in both rural and urban counties. In Appendix Table A9, we split the sample into two groups of counties based on the share of urban population in 1940, i.e., above and below the median. The estimates for 1950 and 1960 are negative and of similar magnitude for both set of counties. Overall, our findings suggest that the negative impact of war casualties on fertility at the county-level is not solely driven by less populous (or rural) counties.

In our main specification, we are controlling for female population. This may be an issue if female population was affected by WWII. Instead of the raw birth counts, we examine the impact of WWII male casualties on birth rates computed as the number of total live births divided by the female population aged between 15 and 44, and multiplied by 100 for each county and decade. Our estimates are presented in Appendix Table A10. ${ }^{19}$ Our main findings remain mostly unchanged and suggest that casualty rates are negatively related to fertility in 1950 and 1960.

To provide a check of whether our findings are driven by states with a large share of black residents, we replicate our baseline analysis, but exclude states where the population is more than $20 \%$ black. The estimates are presented in Appendix Table A12. Our estimates are slightly smaller in magnitude, but have the same sign and remain statistically significant at conventional levels.

\footnotetext{
${ }^{18}$ Weighting counties based on their 1940's population relative to the 1940 U.S. population yields similar results (see Appendix Table A8).

${ }^{19}$ Our results are also robust to controlling for the total population instead of the female population. Appendix Table A11 shows the estimates.
} 
Last, to better understand the distribution of our main independent variable, we illustrate the variation in casualty rates across counties in Appendix Figure A5. The casualty rates' distribution is symmetric and unimodal. Therefore, splitting casualty rates across groups at the median rather than the mean does not affect our main results. (See Appendix Table A13 for the analysis.) The figure also shows a right tail to the distribution suggesting the presence of outliers for the top values of casualty rate. As this might affect our findings when relying on this variable in its continuous form, we exclude the top $1 \%$ of casualty rate counties (i.e., 30 counties with casualty rate above 2.11) in Appendix Table A14. Our results in 1950 hold and become larger in magnitude for the continuous form, while the estimate from the 1960 continuous regression slightly decreases in magnitude and loses its significance. Our estimates in columns 5 and 6 are insignificant and approximatively equal to 0 , confirming the absence of the effect in 1970.

\subsection{Migration}

We now turn to analysing the role of selective migration after the war. Arguably, men residing in counties with relatively fewer casualties might migrate to counties where sex ratios are more imbalanced. There are plausibly better job opportunities in high casualty rate counties and relatively more unmarried women. In other words, geographical differences in the thickness of the job and marriage markets due to the war could lead to selective migration. Selective migration would "compensate" for missing men in high casualty rate counties. We would thus be underestimating the effect of WWII casualties in our baseline analysis. To examine whether our results are driven by selective migration, we repeat our baseline analysis, but exclude counties with very negative and very positive net migration after the war. More precisely, we exclude counties that are below and above one standard deviation from the mean in total net migration, i.e., we restrict the sample to counties in a bandwidth of total net migration between -30 and 10 net migrants per 100 individuals.

Appendix Table A15 presents our estimates for this subset of counties. This table has the same structure as Table 3. The coefficients of interest in columns 1, 3 and 5 are virtually identical to the ones in Table 3, while the estimates for the continuous regressions for the years 1950 and 1960 (columns 2 and 4) are larger in magnitude. 


\section{Channels}

Our findings so far are intriguing because WWII casualties are negatively correlated to fertility during the 1950s relative to before the war. In this section, we discuss different mechanisms through which male casualties could have impacted fertility. We then rely on data at the SEA-level to test some of these channels.

\subsection{Fertility}

Before turning our attention to the mechanisms, we check whether our fertility results are similar at the SEA-level. Appendix Table A16 provides summary statistics. There is a total of 466 SEAs, 243 of which are categorized as high-casualty rate.

Appendix Table A17 presents estimates of equation 1 where the dependent variable is the natural log of total live births. The structure of the table is the same as Table 3. The only differences are that we replace our county fixed effects by SEA fixed effects, and that the standard errors are now clustered at the SEA-level. Our estimates and conclusions are very similar. The estimates are all negative and statistically significant in columns 1-4. The estimated effect remains negative and not statistically significant in 1970, with a smaller magnitude. Of note, estimates from the SEA-level binary measures are not directly comparable to the county-level measures due to the difference in means between groups. Our rescaled coefficient estimate in column 1 suggests that high-casualty rate SEAs had around $8 \%$ fewer total live births compared to those with lower casualty rates, which is close in magnitude to our county-level findings.

\subsection{Mechanisms}

The absence of men during WWII could have led to a slowdown in the fertility increase during the Baby Boom period through many channels. A first mechanism through which WWII casualties may affect fertility is the increase in female employment. During WWII, women across the U.S. were highly encouraged to work in different industries and take over jobs previously done by men. "Rosie the Riveter", a cultural icon of WWII, is now used as a symbol of American feminism and women's economic power. Acemoglu et al. (2004) document that the war induced a large positive shock to the demand for female labor as male mobilization drew many women into the workforce permanently. While men were fighting the war, 
millions of women were drawn into the labor force and replaced men in factories and offices. In the same line, Goldin and Olivetti (2013) provide empirical evidence that married women without children experienced the largest increase in labor force participation and weeks worked.

An increase in the female employment both during and after WWII would potentially lead to a decrease in fertility rates due to an increase in the cost of having and raising a child. In high casualty rate counties, the higher share of women who work have less time to raise children, and thus may decide to have fewer children. ${ }^{20}$

In the "quality-quantity" trade-off theory proposed by Becker (1960), ${ }^{21}$ increases in wages induce parents to substitute the quantity of children for higher quality. Despite the fact that Acemoglu et al. (2004) found that the shift in female labor force participation increased market competition and lowered individual wages, the existence of an additional source of income within a household would have a positive impact on the couple's earnings. An increase in household wages could tempt married couples to favor quality of children over quantity. ${ }^{22}$

\subsection{Quality-Quantity Trade-Off}

We now test whether WWII casualties affected female employment and household income using individual-level data. An increase in household income could lead parents to substitute the quantity of children for higher quality. The econometric model is as follows:

$$
y_{i s t}=\lambda_{s}+\alpha d_{w a r}+\beta d_{w a r} \times R_{s}+X_{i s t}^{\prime} \gamma+\varepsilon_{i s t},
$$

where $y_{i s t}$ is the outcome variable of interest for individual $i$ from SEA $s$ in year $t . R_{s}$ is the casualty rate by SEA, while $d_{w a r}$ equals one in 1950 (post-WWII) and zero in 1940 (pre-WWII). The interaction of $d_{\text {war }}$ and $R_{s s}$ shows the effect of WWII casualties on the outcome variable. $\beta$ is thus

\footnotetext{
${ }^{20}$ A recent study by Vandenbroucke (2014) builds and calibrates a fertility model to fit the birth rate in France from 1800 until World War I (WWI). He finds that the fall in the birth rate during the war is mostly due to the loss of expected income associated with the risk that a wife remains alone. Boehnke and Gay (2017) also provide evidence that areas with relatively more military casualties in France during WWI experienced a larger increase in female labor throughout the interwar period.

${ }^{21} \mathrm{~A}$ vast literature focuses on this channel. See Becker and Barro (1988), Becker and Barro (1989), Galor and Weil (2000), Jones et al. (2011), Albanesi and Olivetti (2014), Manuelli and Seshadri (2009), and Vandenbroucke (2014).

${ }^{22}$ Higher incomes could also facilitate the adoption of modern household technologies (Bose et al. (2020)). Access to modern household technologies would free women's time from basic housework, which may have led to increased investments in children's health (Lewis (2018)).
} 
our coefficient of interest. $X_{i s t}$ is a set of individual characteristics. Our set of (exogenous) individual characteristics includes age, race and ethnicity. We also include the following (potentially endogenous) controls in some specifications: marital status, education and experience. We include SEA fixed effects and report standard errors clustered at the SEA-level.

Table 5 displays the results of this model. Each entry shows the estimate of the interaction term coefficient $\beta$ for a different specification. Columns $1-$ 3 (4-6) present estimates for the binary (continuous) regressions. Columns 1 and 4 only include SEA fixed effects. In columns 2 and 5, we add to the model our set of exogenous controls. Columns 3 and 6 also control for marital status, education level and experience of the individual.

The first and second panels show the effect of WWII casualties on female employment and weeks worked per year for women of childbearing age. The estimates are statistically significant at the $1 \%$ level and suggest that female employment and weeks worked were higher in SEAs with higher casualty rates. The point estimates suggest that female employment in 1950 was 1.1 percentage points higher, and that women of childbearing age worked an additional 1.4 weeks per year, in high casualty rate SEAs. Controlling for age, race and ethnicity does not change the size or significance of the estimates.

These findings provide suggestive evidence that women living in areas with more male casualties were more likely to stay in the labor market (and work more weeks) after the war. ${ }^{23}$ These findings are in line with the idea that decreased fertility in high-casualty rate counties is partly due to the induced shifts in female labor supply during and after WWII.

The third and fourth panels test whether the SEA casualty rate is related to wages and household income. Acemoglu et al. (2004) show that women worked more after the war in states with higher mobilization rates, which lowered female and male wages. Our estimates support their findings, showing that weekly wages for males and females working for at least 35 hours per week were lower in areas where the casualty rate was high. ${ }^{24}$ However, we think it is more relevant to look at the effect of war casualties on the household's income as it relates directly to Becker's quality-quantity

\footnotetext{
${ }^{23}$ It has not been clearly established why so many women stayed in the labor market after the war. Acemoglu et al. (2004) hypothesize that it is possibly due to a change in women's preferences, opportunities and/or information about available work. See Mulligan (1998) for an investigation of the causes of the increase in female labor force participation during WWII.

${ }^{24}$ The sample is restricted to individuals between the age of 15 and 65 . Top-coded values are imputed as 1.5 times the censored value. Farmers, self-employed and unpaid family workers are excluded.
} 
trade-off theory. Our estimates show that the effect of WWII on household income was positive in 1950. More precisely, our estimates suggest that household income was about $3 \%$ higher in areas where the casualty rate was high.

In Panel five, we restrict the sample of women to those who have at least one child. In our sample, $12.2 \%$ (in 1940) and 18.5\% (in 1950) of employed women had at least one child. Restricting the sample to mothers allows us to investigate whether WWII increased women's employment only up to the point that they had a first child. We do not find empirical evidence supporting this idea as our estimates suggest that WWII casualties significantly increased female employment for women with children. ${ }^{25}$

In Table 6 and Appendix Tables A18, A19 and A20, we test whether WWII male casualties differently affected younger and older cohorts. These tables show estimates of equation 2 in its continuous and binary forms, separately. We divide the sample into five age groups: 15 to 24,25 to 34 , 35 to 44, 45 to 54 and 55 to 65 years old. For this analysis, we compare women in each age category in 1950 to women in the same age category in 1940. We include SEA fixed effects and our set of exogenous controls. (See Appendix Tables A18 and A20 for the models including the endogenous controls.)

First, we re-examine the impact on fertility at the individual-level. We rely on the continuous variable "Children under age of 5", which indicates the number of own children age 4 and under residing in the household. We restrict the sample to women who gave birth in the period between 1935 and 1940 (pre-war period) versus the period between 1945 and 1950 (post-war period). Our estimates are large, negative and statistically significant for women under the age of $44 .{ }^{26}$ In contrast, the estimate is a well-estimated zero for older women. Moreover, we rely on the dummy variable "Having a Child" as an alternative fertility measure. We find that WWII casualties had a significantly negative effect on the probability of having a child for women aged between 25 and 34 years old. ${ }^{27}$ (See Appendix Tables A18, A19 and A20.) These results suggest that fertility of women who were of

\footnotetext{
${ }^{25}$ Note that when we restrict our sample to women without children, the effect on female employment is larger (around 0.017 in binary form and 0.070 in continuous form), which partially goes in line with Goldin and Olivetti (2013)'s findings.

${ }^{26}$ The estimated effect on the number of children under the age of 5 for single women is also negative, suggesting a lower number of out of wedlock children in the high-casualty rates areas.

${ }^{27}$ Restricting the sample to women who had at least one child above 5 years old does not change our results. Estimates are all negative, but statistically significant solely for younger women (aged 15 to 25 years old).
} 
childbearing age during WWII was affected the most. The negative effect on all-age fertility rates in 1950 could still be consistent with Doepke et al. (2015)'s findings if a large decrease in fertility among older women offset any rise among younger cohorts. This could be the case in the presence of labor market crowd-out for younger cohorts. We investigate the impact of WWII casualties on labor market outcomes by age group in what follows.

For female employment, our estimates are all positive and statistically significant for women aged 15 to 54 . Interestingly, our estimates show that younger cohorts were affected the most by WWII casualties. The estimates are twice as large for women between the age of 15 and 24 than for women aged 25 to 44, suggesting that there was no labor market crowd-out for younger cohorts. The estimates are also positive and quite large for weeks worked. In the binary regressions (Appendix Tables A19 and A20), highcasualty rate areas had an increase of 1.7 weeks worked for females aged 25 to 35 years old in comparison to a 1 week increase for those in the age category $45-54$.

To examine more closely Becker's trade-off theory and check whether parents in high-casualty rate counties are investing more in the quality of their children, we investigate the impact of WWII casualties on children's health outcomes. ${ }^{28}$ More precisely, we investigate the effect of WWII casualties on the percentage of births attended by physicians at hospital and infant mortality under the age of one. ${ }^{29}$ In our sample, $37.3 \%(79.2 \%)$ of births are attended by physicians at hospital in 1940 (1950). A larger percentage of births attended by skilled health personnel would indicate better health conditions for newborn babies.

Table 7 shows the estimates of the interaction term coefficient in equation 1 on the percentage of births attended by physicians at hospital (columns 1-4) and the natural log of infant mortality under the age of one (columns 5-6). ${ }^{30}$ Results suggest that WWII male casualties had a positive effect on the percentage of births attended by physicians at hospital in 1950 and 1959 (data not available in 1960). Moreover, column 6 shows that a 1 per-

\footnotetext{
${ }^{28}$ The Veterans Affairs (VA) health care system grew enormously in the decades following WWII. This could be an issue if spouses of veterans could deliver in VA hospitals. The Department of Veterans Affairs confirmed us that (1) women were not uniformly considered as a regular part of the military during WWII, (2) VA did not include maternity benefits in the medical benefits package, and (3) male veterans' nonveteran spouses have never been covered by VA hospitals.

${ }^{29}$ In our sample, infant mortality was about $5.5 \%$ in 1940 and decreased to approximately $4.1 \%$ by 1950 .

${ }^{30}$ Note that many counties have missing information for infant mortality under the age of one. We report estimates using a balanced sample of counties. The estimates using an unbalanced sample of counties are strikingly similar.
} 
centage point increase in the male casualty rate during WWII leads to a $21.65 \%$ decrease in infant mortality in 1960.

We plot yearly estimates of the effect of WWII casualties on attended births and infant mortality in Appendix Figures A6 and A7, respectively. County-level data on births by attendant by place of residence is available between 1939 and 1959. For infant mortality, data is available by place of occurrence from 1915 to 1941, and from 1959 to 1972. For the impact on births attended by physicians, estimates show that the effect begins in 1941 and decreases in magnitude during the late 1950s. As for the impact on infant mortality, parallel trends can be observed in the period between 1935 and 1939. Again, the effect starts to quick in as early as 1941, is significantly negative in the period between 1959 and 1966, and starts to decrease in magnitude until it fades away completely in late 1960s. These findings suggest that the pattern of the channels at play fits the pattern of our main effect on total live births in Figure 4.

To sum up, our findings provide suggestive evidence that WWII casualties increased female employment and household income in 1950. These results could explain the lower increase in fertility in high-casualty rate areas through Becker's quality-quantity trade-off theory. Parents in highcasualty counties earn more and may thus invest to a greater extent in their children's human capital.

\subsection{Sex Ratios and Marriage Market}

Another mechanism through which conflict may affect fertility is sex ratios. $^{31}$ The war could have affected women's chance of finding a partner especially in areas where mobilization or casualty rates were high, and thus delay the age of having a first child.

In the sixth panel of Table 5, we test whether WWII casualties affected the probability of getting married for women of childbearing age (between 15 and 44). To capture the direct effect of WWII on the marriage market outcomes, we restrict the sample to include only women who got married in the last 10 years. ${ }^{32}$ The dependent variable in the seventh panel is the age at first birth. In the eighth panel, we focus on first marriages and

\footnotetext{
${ }^{31}$ Another channel through which war may impact fertility is trauma. Festy (1984) argues that during a troubled period, feasible births decline while desired births remain constant. Caldwell (2004) empirically examines 13 social crises from the English Civil War in the 1600 s to the fall of communism, and finds remarkable drops in birth rates in each of the cases. This direct impact of conflict remains less important in the case of the U.S. in WWII since attacks on American soil were very limited.

${ }^{32}$ Since most women were married by the age of 30 in 1950 , this sample restriction allows us to restrict the treated group to women who got married during or after WWII.
} 
examine the effect of male casualties on the spousal age gap. Our results suggest that WWII casualties did not significantly affect women's marriage rates, the age of becoming a mother, nor the age difference between married couples. ${ }^{33}$ The estimates are all small, positive and statistically insignificant at conventional levels.

We also check the impact of WWII casualties on marital outcomes by age category in Table 6 and Appendix Tables A18, A19 and A20. We do not find strong evidence that WWII casualties had any effect on marriage rates and the age gap at marriage for all the age subgroups. ${ }^{34}$ One exception is for the age at first birth for women between 15 and 25. Our estimates suggest that WWII casualties led to a significant increase for these women who were most likely unmarried during WWII and reached their childbearing age during or after war (aged 10 to 15 years old in 1945).

Overall, our results suggest that the lower increase in fertility in highcasualty counties is most likely driven by an increase in female employment and household' income rather than male scarcity and lower probability of finding a partner. Our finidngs are in line with Cardoso and Morin (2018) who argue that a sex ratio imbalance in Portugal has led to an increase in female labor force participation but had no effect on the marriage market. ${ }^{35}$

\section{Conclusion}

The United States underwent major demographic and economic changes following WWII. In an unprecedented rise in fertility, 76 million children were born between 1946 and 1964. In this study, we investigate whether this Baby Boom might have been a consequence of WWII. We identify the impact of WWII using male casualties at the state, county and state economic area-levels and show that the fertility rise in 1950 relative to 1940 was smaller in counties (states) where the casualty (or mobilization) rate was high. The negative effect of casualties on births started to decrease in 1960 and vanished by 1970 .

There is considerable evidence that World War II led to a large shift in women's economic role. Based on our findings, it seems that WWII casu-

\footnotetext{
${ }^{33}$ Additionally, we observe no effect of WWII male casualties on divorce.

${ }^{34}$ Examining the effect of WWII casualties on the proportion of women ever married yields similar conclusions as we observe no effect for young women.

${ }^{35} \mathrm{~A}$ plausible explanation of the absence of the effect on marriage is that WWII casualties had a very small impact on sex ratio imbalance. We compute the sex ratio at the SEA-level in Appendix Table A21 and find that the decrease is low (around 4\% in the continuous regression), suggesting that U.S. casualties had a little impact on sex ratio imbalance.
} 
alties slowed down the Baby Boom, especially since the opportunity cost of having a child was higher for working women. Moreover, our empirical findings suggest that 1950 household incomes increased more in areas with higher casualty rates. Overall, our results are consistent with Becker and Barro (1989)'s quality/quantity of children theory. WWII led to an increase in female employment and households' income, which had persistent effects through the 1950s for counties with many missing men. 


\section{References}

Abramitzky, R., Delavande, A. and Vasconcelos, L.: 2011, Marrying up: The role of sex ratio in assortative matching, American Economic Journal: Applied Economics 3(3), 124-57.

Acemoglu, D., Autor, D. H. and Lyle, D.: 2004, Women, war, and wages: The effect of female labor supply on the wage structure at midcentury, Journal of Political Economy 112(3), 497-551.

Albanesi, S. and Olivetti, C.: 2014, Maternal health and the baby boom, Quantitative Economics 5(2), 225-269.

Bailey, M., Clay, K., Fishback, P., Haines, M., Kantor, S., Severnini, E. and Wentz, A.: 2016, U.S. county-level natality and mortality data, 19152007, Inter-university Consortium of Political and Social Research .

Bailey, M. J. and Collins, W. J.: 2011, Did improvements in household technology cause the baby boom? Evidence from electrification, appliance diffusion, and the amish, American Economic Journal: Macroeconomics $\mathbf{3}(2), 189-217$.

Becker, G. S.: 1960, An economic analysis of fertility, Demographic and Economic Change in Developed Countries, Columbia University Press, pp. 209-240.

Becker, G. S. and Barro, R. J.: 1988, A reformulation of the economic theory of fertility, Quarterly Journal of Economics 103(1), 1-25.

Becker, G. S. and Barro, R. J.: 1989, Fertility choice in a model of economic growth, Econometrica 57(2), 481-501.

Becker, G. S. and Lewis, H. G.: 1973, On the interaction between the quantity and quality of children, Journal of Political Economy 81(2, Part 2), S279-S288.

Bellou, A. and Cardia, E.: 2014, Baby-boom, baby-bust and the great depression. IZA Discussion Paper 8727.

Bellou, A. and Cardia, E.: 2016, Occupations after WWII: The legacy of rosie the riveter, Explorations in Economic History 62, 124-142.

Bethmann, D. and Kvasnicka, M.: 2013, World War II, missing men and out of wedlock childbearing, Economic Journal 123(567), 162-194. 
Blau, F. D., Ferber, M. A. and Winkler, A. E.: 2002, The economics of women, men, and work, Prentice-Hall Englewood Cliffs, NJ.

Boehnke, J. and Gay, V.: 2017, The missing men: World war I and female labor participation. MPRA Paper 77560.

Bogue, D. J.: 1951, State economic areas: A description of the procedure used in making a functional grouping of the counties of the United States, US Government Printing Office.

Bose, G., Jain, T. and Walker, S.: 2020, Women's labor force participation and household technology adoption. UNSW Economics Working Paper.

Brainerd, E.: 2017, The lasting effect of sex ratio imbalance on marriage and family: Evidence from World War II in Russia, Review of Economics and Statistics 99(2), 229-242.

Bristol, D. W. and Stur, H. M.: 2002, Integrating the US military: Race, gender, and sexual orientation since World War II, Baltimore, MD: Johns Hopkins University Press.

Caldwell, J. C.: 2004, Social upheaval and fertility decline, Journal of Family History 29(4), 382-406.

Cardoso, A. R. and Morin, L.-P.: 2018, Can Economic pressure overcome social norms? The case of female labor force participation. IZA Discussion Paper 11822.

Carranza, E.: 2014, Soil endowments, female labor force participation, and the demographic deficit of women in India, American Economic Journal: Applied Economics 6(4), 197-225.

Doepke, M., Hazan, M. and Maoz, Y. D.: 2015, The baby boom and World War II: A macroeconomic analysis, Review of Economic Studies 82(3), 1031-1073.

Easterlin, R. A.: 1961, The American baby boom in historical perspective, American Economic Review 51(5), 869-911.

Eder, C.: 2016, Missing men: World War II casualties and structural change. Working Papers in Economics and Statistics number 22.

Fernández, R.: 2013, Cultural change as learning: The evolution of female labor force participation over a century, American Economic Review 103(1), 472-500. 
Fernández, R., Fogli, A. and Olivetti, C.: 2004, Mothers and sons: Preference formation and female labor force dynamics, Quarterly Journal of Economics 119(4), 1249-1299.

Fernández, R. and Wong, J.: 2014a, Unilateral Divorce, the decreasing gender gap, and married women's labor force participation, American Economic Review 104(5), 342-47.

Fernández, R. and Wong, J. C.: 2014b, Divorce risk, wages and working wives: A quantitative life-cycle analysis of female labour force participation, Economic Journal 124(576), 319-358.

Festy, P.: 1984, Effets et répercussions de la première guerre mondiale sur la fécondité française, Population 39(6), 977-1010.

Galor, O. and Weil, D. N.: 2000, Population, technology, and growth: From Malthusian stagnation to the demographic transition and beyond, American Economic Review 90(4), 806-828.

Goldin, C.: 2006, The quiet revolution that transformed women's employment, education, and family, American Economic Review 96(2), 1-21.

Goldin, C. D.: 1991, The role of World War II in the rise of women's employment, American Economic Review 81(4), 741-756.

Goldin, C. and Katz, L. F.: 2002, The power of the pill: Oral contraceptives and women's career and marriage decisions, Journal of Political Economy 110(4), 730-770.

Goldin, C. and Olivetti, C.: 2013, Shocking labor supply: A reassessment of the role of World War II on women's labor supply, American Economic Review: Papers \&6 Proceedings 103(3), 257-62.

Greenwood, J., Seshadri, A. and Vandenbroucke, G.: 2005, The baby boom and baby bust, American Economic Review 95(1), 183-207.

Grosjean, P. and Khattar, R.: 2019, It's raining men! Hallelujah?: The long-run consequences of male-biased sex ratios, Review of Economic Studies 86(2), 723-754.

Guinnane, T. W.: 2011, The historical fertility transition: A guide for economists, Journal of Economic Literature 49(3), 589-614. 
Jaworski, T.: 2014, "You're in the army now:" The impact of World War II on women's education, work, and family, Journal of Economic History 74(1), 169-195.

Jenkins, M. D., Gregory, F. A., Long, H. H., McAllister, J. E. and Thompson, C. H.: 1944, The Black and white of rejections for military service: A study of rejections of selective service registrants, by race, on account of educational and mental deficiencies, The Association.

Jones, L. E. and Schoonbroodt, A.: 2016, Baby busts and baby booms: The fertility response to shocks in dynastic models, Review of Economic Dynamics 22, 157-178.

Jones, L., Schoonbroodt, A. and Tertilt, M.: 2011, Fertility theories: Can they explain the negative fertility-income relationship?, Demography and the Economy, University of Chicago Press, chapter 2, pp. 43-100.

Lafortune, J.: 2013, Making yourself attractive: Pre-marital investments and the returns to education in the marriage market, American Economic Journal: Applied Economics 5(2), 151-78.

Lesthaeghe, R. and Surkyn, J.: 1988, Cultural dynamics and economic theories of fertility change, Population and Development Review 14(1), 145 .

Lewis, J.: 2018, Infant health, women's fertility, and rural electrification in the United States, 1930-1960, Journal of Economic History 78(1), 118154 .

Manuelli, R. E. and Seshadri, A.: 2009, Explaining international fertility differences, Quarterly Journal of Economics 124(2), 771-807.

Mulligan, C. B.: 1998, Pecuniary incentives to work in the United States during World War II, Journal of Political Economy 106(5), 1033-1077.

Oster, E.: 2019, Unobservable selection and coefficient stability: Theory and evidence, Journal of Business and Economic Statistics 37(2), 187204.

Qian, N.: 2008, Missing women and the price of tea in China: The effect of sex-specific earnings on sex imbalance, Quarterly Journal of Economics 123(3), 1251-1285. 
Ruggles, S., McCaa, R. and Sobek, M.: 2010, IPUMS-international statistical disclosure controls, J. Domingo-Ferrer and E. Magkos (Eds.) LNCS 6344, 74-84.

Rutherdale, R.: 1999, Fatherhood, masculinity, and the good life during Canada's baby boom, 1945-1965, Journal of Family History 24(3), 351373.

Sandler, S.: 1992, Segregated skies: All-black combat squadrons of WWII, Smithsonian Institution Press, Washington, DC.

Vandenbroucke, G.: 2014, Fertility and wars: The case of World War I in France, American Economic Journal: Macroeconomics 6(2), 108-36.

Wynn, N. A.: 1993, The Afro-American and the Second World War, Holmes \& Meier, New York. 


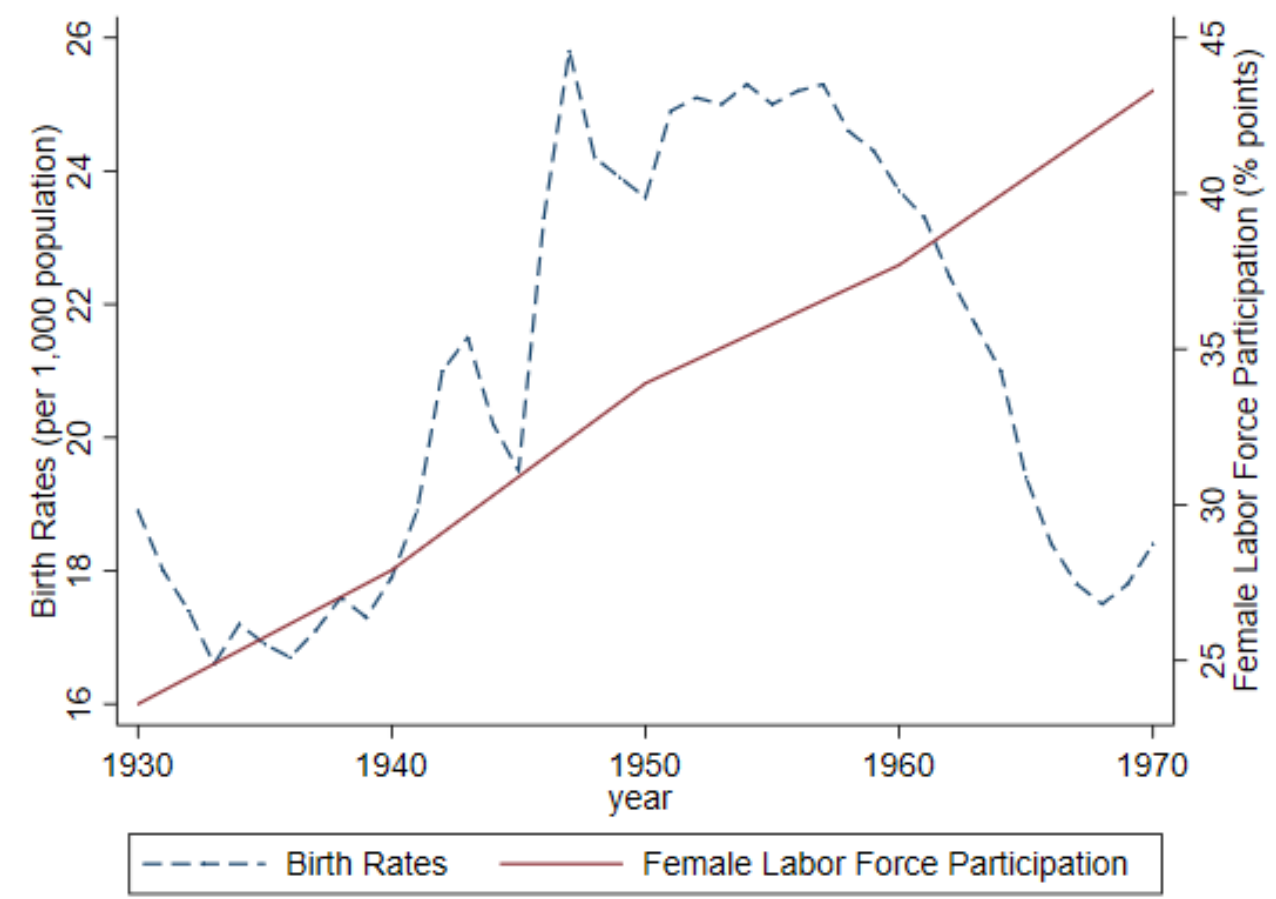

Figure 1: Birth rates and female labor force participation in the U.S. Sources: Vital Statistics for data on births rates. See Blau et al. (2002) for data on female participation rates.

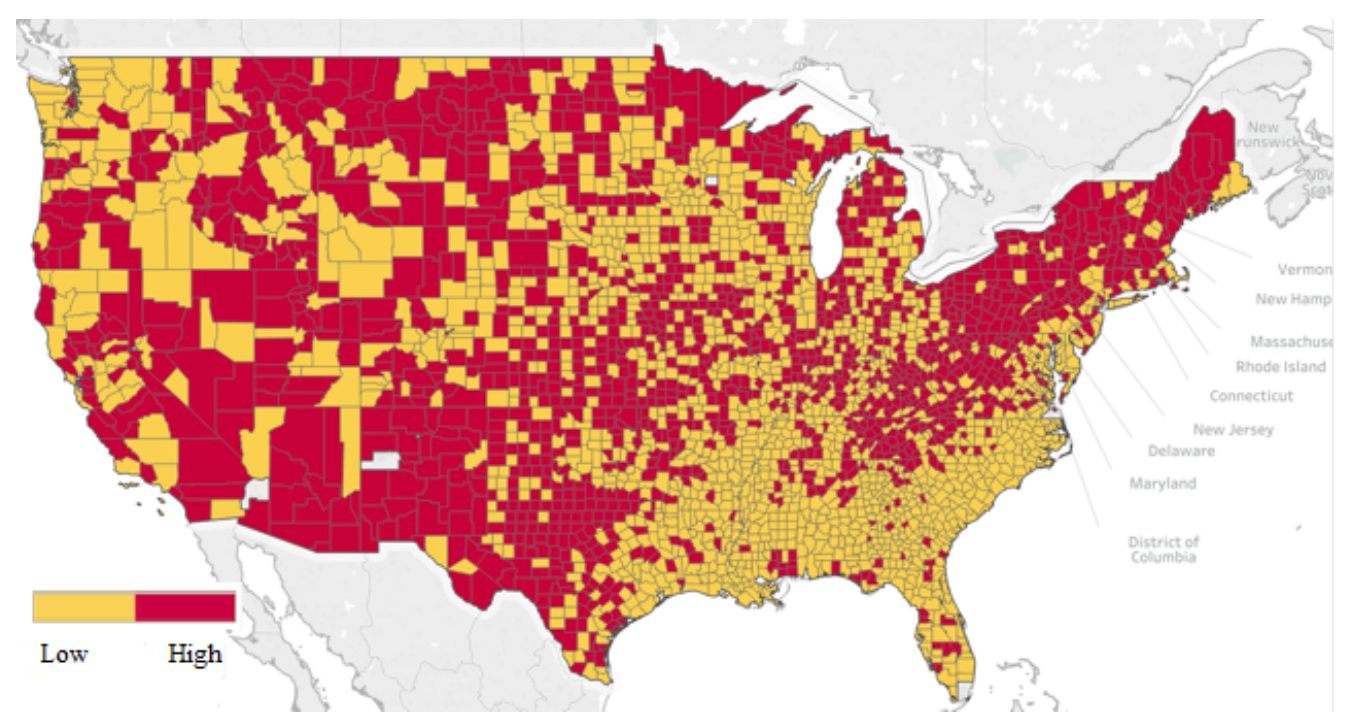

Figure 2: County-level geographic distribution of low and high casualty rates. 

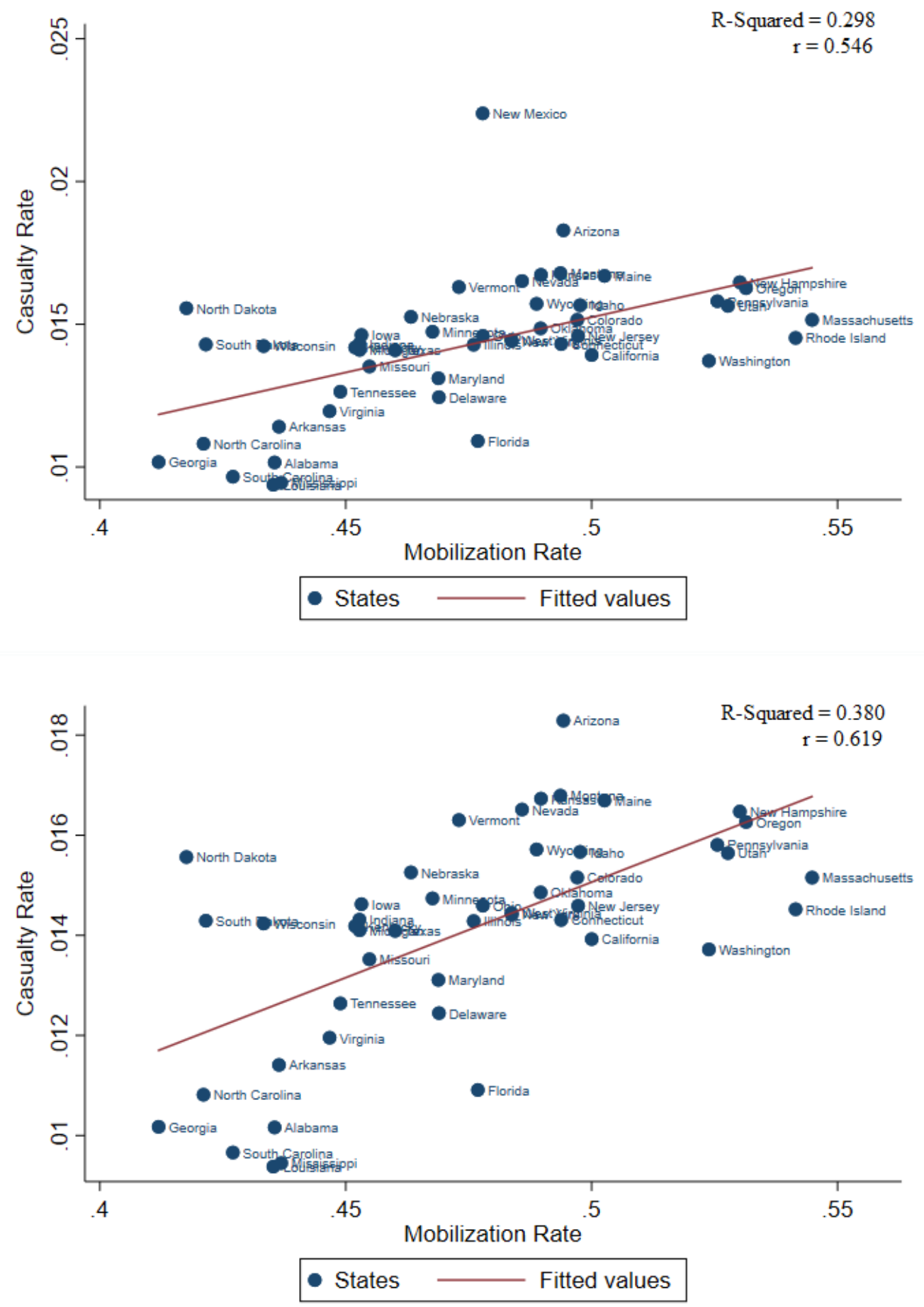

Figure 3: Correlation between mobilization rate and casualty rate at the state level, with and without New Mexico state. Source: Mobilization rates are from Acemoglu et al. (2004). 


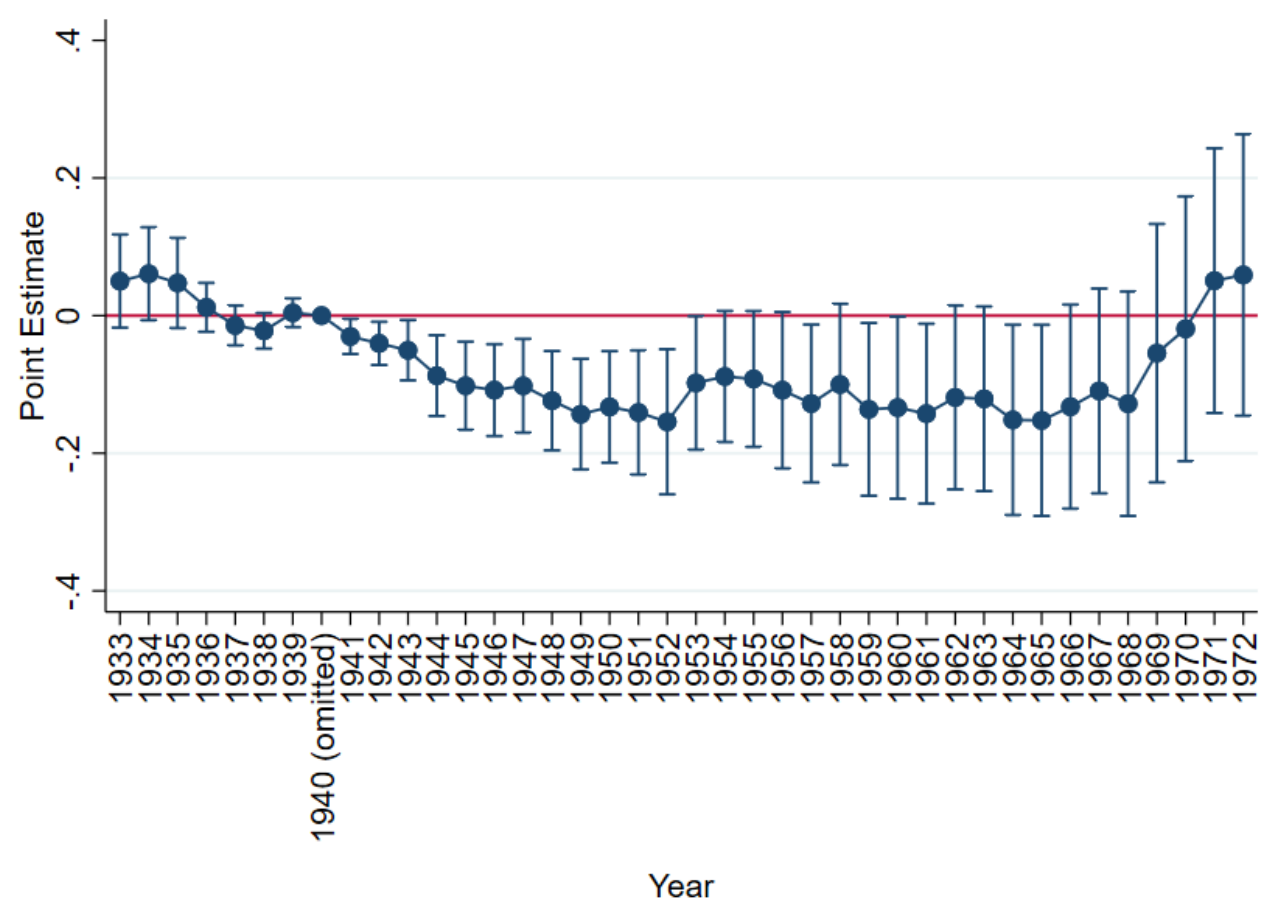

Figure 4: This figure plots the estimated coefficients from the continuous regression on the natural log of total births by place of occurrence in the United States between 1933 and 1972. The year 1940 is omitted from the regression, i.e., omitted category. Source: U.S. County-Level Natality and Mortality Data, 1915-2007 (Bailey et al. 2016). Note that data on births by place of occurrence begins to be complete in the dataset starting 1933 . 
Table 1: Demographic Characteristics in Low and High Casualty Rate Counties

\begin{tabular}{|c|c|c|c|c|c|c|}
\hline & \multicolumn{2}{|c|}{ All Counties } & \multicolumn{2}{|c|}{ L Low Rate Counties } & \multicolumn{2}{|c|}{$\overline{\text { High Rate }}$ Counties } \\
\hline & Mean & S.D. & Mean & S.D. & Mean & S.D. \\
\hline \multicolumn{7}{|l|}{ Panel A: } \\
\hline Casualties & 98.5 & 421.7 & 98.9 & 542.4 & 98.0 & 211.6 \\
\hline Men Population $_{18-44}$ & 10157 & 46545 & 11633 & 61007 & 8465 & 19518 \\
\hline Casualty Rates & 1.001 & 0.391 & 0.776 & 0.175 & 1.260 & 0.411 \\
\hline \multicolumn{7}{|l|}{ Panel B: } \\
\hline Total Live Births 1940 & 758 & 2,802 & 853 & 3,629 & 650 & 1,321 \\
\hline Total Live Births 1950 & 1,136 & 4,556 & 1,289 & 5,856 & 961 & 2,279 \\
\hline Total Live Births 1960 & 1,351 & 5,659 & 1,534 & 7,218 & 1,142 & 2,990 \\
\hline Total Live Births 1970 & 1,185 & 5,068 & 1,353 & 6,446 & 992 & 2,724 \\
\hline
\end{tabular}

Panel C:

Female Population 1940

Female Population 1950

10,305

49,306

11,884

64,672

8,497

20,508

Female Population 1960

11,557

50,717

12,589

66,146

9,165

22,380

Female Population 1970

13,585

56,129

13,122

63,746

9,761

24,831

Observations

3,070

1,639

1,431

Notes: Data are from the National Archives monographs and National Historical Geographic Information System. County casualty rate is the number of casualties divided by the number of men aged between 18 and 44 in 1940, multiplied by 100. "Female population" represents the total number of females of childbearing age per county. There are a total of 3,070 counties. We use the casualty rate mean to split the sample into two categories. There are 1,639 counties in the "Low Rate Counties" category and 1,431 counties in the "High Rate Counties" category. Alaska, the District of Columbia and Hawaii are not included in the analysis. The number of casualties is not available for Virginia cities, except for Alexandria city which is included in Arlington county. Bronx, Queens, New York, Richmond, and Kings counties are all included in New York City. 
Table 2: Estimates of the impact of WWII Casualties and Mobilization at the State-Level

\begin{tabular}{|c|c|c|c|c|c|c|c|c|}
\hline \multirow[b]{3}{*}{ Dependent Variable } & \multicolumn{4}{|c|}{ Census Data } & \multicolumn{4}{|c|}{ Vital Statistics Data } \\
\hline & \multicolumn{2}{|c|}{ Binary } & \multicolumn{2}{|c|}{ Cont. } & \multicolumn{2}{|c|}{ Binary } & \multicolumn{2}{|c|}{ Cont. } \\
\hline & (1) & $(2)$ & $(3)$ & $(4)$ & $(5)$. & (6) & $(7)$ & $(8)$ \\
\hline \multicolumn{9}{|c|}{$\begin{array}{l}\text { Panel A: } \\
\text { Casualties × After War 1940-1960 }\end{array}$} \\
\hline Children Under Age of 5 & $\begin{array}{c}0.022 \\
(0.020)\end{array}$ & $\begin{array}{c}-0.023 \\
(0.020)\end{array}$ & $\begin{array}{c}0.085 \\
(0.062)\end{array}$ & $\begin{array}{c}-0.121 \\
(0.080)\end{array}$ & & & & \\
\hline Log of Total Live Births & & & & & $\begin{array}{c}0.038 \\
(0.036)\end{array}$ & $\begin{array}{l}-0.054 \\
(0.034)\end{array}$ & $\begin{array}{c}0.010 \\
(0.086)\end{array}$ & $\begin{array}{l}-0.206 \\
(0.115)\end{array}$ \\
\hline \multicolumn{9}{|c|}{$\begin{array}{l}\text { Panel B: } \\
\text { Mobilization } \times \text { After War 1940-1960 }\end{array}$} \\
\hline Children Under Age of 5 & $\begin{array}{c}0.025 \\
(0.020)\end{array}$ & $\begin{array}{l}-0.041 \\
(0.016)\end{array}$ & $\begin{array}{c}0.652 \\
(0.318)\end{array}$ & $\begin{array}{l}-0.290 \\
(0.257)\end{array}$ & & & & \\
\hline Log of Total Live Births & & & & & $\begin{array}{c}0.037 \\
(0.042)\end{array}$ & $\begin{array}{l}-0.024 \\
(0.037)\end{array}$ & $\begin{array}{c}0.936 \\
(0.491)\end{array}$ & $\begin{array}{l}-0.347 \\
(0.554)\end{array}$ \\
\hline State FE & $\checkmark$ & $\checkmark$ & $\checkmark$ & $\checkmark$ & $\checkmark$ & $\checkmark$ & $\checkmark$ & $\checkmark$ \\
\hline Exogenous Controls & $\checkmark$ & $\checkmark$ & $\checkmark$ & $\checkmark$ & & & & \\
\hline Endogenous Controls & $\checkmark$ & $\checkmark$ & $\checkmark$ & $\checkmark$ & & & & \\
\hline Female Population & & & & & $\checkmark$ & $\checkmark$ & $\checkmark$ & $\checkmark$ \\
\hline Black Population $_{1940}$ & & $\checkmark$ & & $\checkmark$ & & $\checkmark$ & & $\checkmark$ \\
\hline Years of Education 1940 & & $\checkmark$ & & $\checkmark$ & & $\checkmark$ & & $\checkmark$ \\
\hline Fathers Share $_{1940}$ & & $\checkmark$ & & $\checkmark$ & & $\checkmark$ & & $\checkmark$ \\
\hline \# of States & 48 & 48 & 48 & 48 & 48 & 48 & 48 & 48 \\
\hline Observations & 242,833 & 242,833 & 242,833 & 242,833 & 96 & 96 & 96 & 96 \\
\hline R-Squared & 0.169 & 0.170 & 0.169 & 0.170 & 0.962 & 0.979 & 0.962 & 0.980 \\
\hline Oster $\delta$ for $\beta=0$ & & -0.027 & & -0.021 & & -0.320 & & -0.780 \\
\hline
\end{tabular}

Notes: Estimates in columns 1-4 are from separate regressions using pooled micro data from the 1940 and 1960 censuses. Estimates in columns 5-8 are from separate regressions using Vital Statistics data (1940 and 1960). Each outcome variable in panel A is regressed on the World War II casualty rate interacted with a 1960 year indicator variable. Each outcome variable in panel B is regressed on the World War II mobilization rate interacted with a 1960 year indicator variable. The variable "Children Under Age of 5 " indicates the number of own children age 4 and under residing with each individual for women aged 25 to 35. Exogenous controls include age, race and ethnicity. Endogenous controls include the education level and marital status. State fixed effects are included for all regressions. We control for pre-war state socioeconomic characteristics that may have caused differences in casualties: "Black Population Share in 1940" as the number of black men aged between 18 and 44 divided by the total population of men in the same age group, "Fathers Share in 1940" as the share of men between 18 and 44 years old who are married and have at least one child, and "Average Years of Education in 1940" as the state-average years of education for men between 18 and 44 years old. Controls are all interacted with the "After War" dummy. Census samples exclude individuals living in institutional group quarters and include person weights used in all calculations. Alaska, the District of Columbia and Hawaii are not included in the analysis. The Oster (2019) tests in columns $2,4,6$, and 8 are each with reference to the baseline specification in columns $1,3,5$, and 7 (respectively) with only basic controls and state fixed effects. $R_{\max }$ is set to $1.3 \mathrm{R}$ following Oster's suggestion (with upper limit equals to one). Standard errors in parentheses are clustered at the state-level. 
Table 3: Impact of World War II Casualties on Fertility

\begin{tabular}{|c|c|c|c|c|c|c|}
\hline & \multicolumn{6}{|c|}{ Dependent Variable: Log of Total Live Births } \\
\hline & \multicolumn{2}{|c|}{$1940-1950$} & \multicolumn{2}{|c|}{ 1940-1960 } & \multicolumn{2}{|c|}{ 1940-1970 } \\
\hline & $\begin{array}{l}\text { Binary } \\
\text { (1) }\end{array}$ & $\begin{array}{l}\text { Cont. } \\
(2)\end{array}$ & $\begin{array}{l}\text { Binary } \\
(3)\end{array}$ & $\begin{array}{l}\text { Cont. } \\
\text { (4) }\end{array}$ & $\begin{array}{l}\text { Binary } \\
\quad(5)\end{array}$ & $\begin{array}{c}\text { Cont. } \\
(6)\end{array}$ \\
\hline After War & $\begin{array}{c}0.093 \\
(0.016)\end{array}$ & $\begin{array}{c}0.215 \\
(0.041)\end{array}$ & $\begin{array}{c}0.006 \\
(0.027)\end{array}$ & $\begin{array}{c}0.178 \\
(0.068)\end{array}$ & $\begin{array}{l}-0.605 \\
(0.036)\end{array}$ & $\begin{array}{l}-0.509 \\
(0.088)\end{array}$ \\
\hline $\begin{array}{l}\text { Casualty Rate } \times \\
\text { After War }\end{array}$ & $\begin{array}{l}-0.097 \\
(0.025)\end{array}$ & $\begin{array}{l}-0.166 \\
(0.040)\end{array}$ & $\begin{array}{l}-0.050 \\
(0.047)\end{array}$ & $\begin{array}{l}-0.194 \\
(0.067)\end{array}$ & $\begin{array}{l}-0.013 \\
(0.054)\end{array}$ & $\begin{array}{l}-0.103 \\
(0.086)\end{array}$ \\
\hline Female Population & $\checkmark$ & $\checkmark$ & $\checkmark$ & $\checkmark$ & $\checkmark$ & $\checkmark$ \\
\hline County FE & $\checkmark$ & $\checkmark$ & $\checkmark$ & $\checkmark$ & $\checkmark$ & $\checkmark$ \\
\hline \# of Counties & 3,069 & 3,069 & 3,066 & 3,066 & 3,062 & 3,062 \\
\hline Observations & 6,138 & 6,138 & 6,132 & 6,132 & 6,124 & 6,124 \\
\hline R-Squared & 0.194 & 0.197 & 0.246 & 0.249 & 0.339 & 0.339 \\
\hline
\end{tabular}

Notes: The dependent variable is the natural $\log$ of total live births. In the binary regressions (columns 1, 3 and 5), "Casualty Rate" is a dummy that takes the value of one for high casualty rate counties and zero for low casualty rate counties. In the continuous regressions (columns 2, 4 and 6), "Casualty Rate" is a continuous variable expressed as the number of casualties per 100 men. "After War" is a dummy that takes the value of one in 1950, 1960 or 1970 . County fixed effects and the natural log of female population are included in all regressions. Alaska, the District of Columbia and Hawaii are not included in the analysis. The number of casualties is not available for most Virginia cities, except for Alexandria city which is included in Arlington county. Bronx, Queens, New York, Richmond, and Kings counties are all included in New York City. The decrease in the number of observations is due to missing data on total live births for some counties in 1950, 1960 and 1970. Moreover, 1970 data on female population is missing for Carson City and Ormbsy in Nevada. Standard errors in parentheses are clustered at the county-level. 
Table 4: Impact of World War II Casualties on Fertility: State-Decade FE

\begin{tabular}{|c|c|c|c|c|c|c|}
\hline & \multicolumn{6}{|c|}{ Dependent Variable: Log of Total Live Births } \\
\hline & \multicolumn{2}{|c|}{$1940-1950$} & \multicolumn{2}{|c|}{ 1940-1960 } & \multicolumn{2}{|c|}{ 1940-1970 } \\
\hline & $\begin{array}{l}\text { Binary } \\
\text { (1) }\end{array}$ & $\begin{array}{l}\text { Cont. } \\
(2)\end{array}$ & $\begin{array}{l}\text { Binary } \\
(3)\end{array}$ & $\begin{array}{l}\text { Cont. } \\
\text { (4) }\end{array}$ & $\begin{array}{l}\text { Binary } \\
\quad(5)\end{array}$ & $\begin{array}{c}\text { Cont. } \\
(6)\end{array}$ \\
\hline After War & $\begin{array}{c}0.259 \\
(0.087)\end{array}$ & $\begin{array}{c}0.331 \\
(0.092)\end{array}$ & $\begin{array}{c}0.323 \\
(0.088)\end{array}$ & $\begin{array}{c}0.449 \\
(0.104)\end{array}$ & $\begin{array}{l}-0.217 \\
(0.159)\end{array}$ & $\begin{array}{l}-0.159 \\
(0.180)\end{array}$ \\
\hline $\begin{array}{l}\text { Casualty Rate } \times \\
\text { After War }\end{array}$ & $\begin{array}{l}-0.059 \\
(0.027)\end{array}$ & $\begin{array}{l}-0.108 \\
(0.040)\end{array}$ & $\begin{array}{l}-0.021 \\
(0.043)\end{array}$ & $\begin{array}{l}-0.144 \\
(0.065)\end{array}$ & $\begin{array}{l}-0.023 \\
(0.055)\end{array}$ & $\begin{array}{l}-0.071 \\
(0.089)\end{array}$ \\
\hline Female Population & $\checkmark$ & $\checkmark$ & $\checkmark$ & $\checkmark$ & $\checkmark$ & $\checkmark$ \\
\hline State-Decade FE & $\checkmark$ & $\checkmark$ & $\checkmark$ & $\checkmark$ & $\checkmark$ & $\checkmark$ \\
\hline County FE & $\checkmark$ & $\checkmark$ & $\checkmark$ & $\checkmark$ & $\checkmark$ & $\checkmark$ \\
\hline \# of Counties & 3,069 & 3,069 & 3,066 & 3,066 & 3,062 & 3,062 \\
\hline Observations & 6,138 & 6,138 & 6,132 & 6,132 & 6,124 & 6,124 \\
\hline R-Squared & 0.237 & 0.238 & 0.309 & 0.311 & 0.419 & 0.419 \\
\hline
\end{tabular}

Notes: The dependent variable is the natural log of total live births. In the binary regressions (columns 1, 3 and 5), "Casualty Rate" is a dummy that takes the value of one for high casualty rate counties and zero for low casualty rate counties. In the continuous regressions (columns 2, 4 and 6), "Casualty Rate" is a continuous variable. "After War" is a dummy that takes the value of one in 1950, 1960 or 1970. County fixed effects and the natural $\log$ of female population are included in all regressions. Additionally, all specifications include state times decade fixed effects. Alaska, the District of Columbia and Hawaii are not included in the analysis. The number of casualties is not available for most Virginia cities, except for Alexandria city which is included in Arlington county. Bronx, Queens, New York, Richmond, and Kings counties are all included in New York City. The decrease in the number of observations is due to missing data on total live births for some counties in 1950, 1960 and 1970. Moreover, 1970 data on female population is missing for Carson City and Ormbsy in Nevada. Standard errors in parentheses are clustered at the county-level. 
Table 5: Impact of World War II Casualties on Women's Economic Outcomes

\begin{tabular}{|c|c|c|c|c|c|c|}
\hline Dependent Variables & (1) & $\begin{array}{c}940-1950 \\
\text { Binary } \\
(2)\end{array}$ & $(3)$ & (4) & $\begin{array}{c}1940-1950 \\
\text { Continuous } \\
(5)\end{array}$ & (6) \\
\hline Employed & $\begin{array}{c}0.011 \\
(0.004)\end{array}$ & $\begin{array}{c}0.011 \\
(0.004)\end{array}$ & $\begin{array}{c}0.015 \\
(0.005)\end{array}$ & $\begin{array}{c}0.050 \\
(0.012)\end{array}$ & $\begin{array}{c}0.047 \\
(0.012)\end{array}$ & $\begin{array}{c}0.072 \\
(0.014)\end{array}$ \\
\hline$N$ & & 742,824 & & & 742,824 & \\
\hline Weeks Worked & $\begin{array}{c}1.429 \\
(0.382)\end{array}$ & $\begin{array}{c}1.410 \\
(0.387)\end{array}$ & $\begin{array}{c}1.619 \\
(0.438)\end{array}$ & $\begin{array}{c}6.154 \\
(0.724)\end{array}$ & $\begin{array}{c}6.017 \\
(0.737)\end{array}$ & $\begin{array}{c}7.337 \\
(0.844)\end{array}$ \\
\hline$N$ & & 742,824 & & & 742,824 & \\
\hline $\begin{array}{l}\text { Log Individual } \\
\text { Weekly Wages }\end{array}$ & $\begin{array}{l}-0.017 \\
(0.017)\end{array}$ & $\begin{array}{l}-0.014 \\
(0.015)\end{array}$ & $\begin{array}{l}-0.013 \\
(0.015) \\
\end{array}$ & $\begin{array}{l}-0.214 \\
(0.068) \\
\end{array}$ & $\begin{array}{l}-0.143 \\
(0.055)\end{array}$ & $\begin{array}{l}-0.143 \\
(0.053)\end{array}$ \\
\hline$N$ & & 292,306 & & & 292,306 & \\
\hline $\begin{array}{l}\text { Log Household } \\
\text { Income }\end{array}$ & $\begin{array}{c}0.038 \\
(0.016) \\
\end{array}$ & $\begin{array}{c}0.032 \\
(0.014) \\
\end{array}$ & $\begin{array}{c}0.044 \\
(0.013) \\
\end{array}$ & $\begin{array}{c}0.104 \\
(0.046) \\
\end{array}$ & $\begin{array}{c}0.113 \\
(0.042) \\
\end{array}$ & $\begin{array}{c}0.157 \\
(0.039) \\
\end{array}$ \\
\hline$N$ & & 286,625 & & & 286,625 & \\
\hline $\begin{array}{l}\text { Employed } \\
\text { with Child }\end{array}$ & $\begin{array}{c}0.008 \\
(0.004)\end{array}$ & $\begin{array}{c}0.008 \\
(0.004)\end{array}$ & $\begin{array}{c}0.007 \\
(0.004)\end{array}$ & $\begin{array}{c}0.046 \\
(0.015)\end{array}$ & $\begin{array}{c}0.041 \\
(0.015)\end{array}$ & $\begin{array}{c}0.039 \\
(0.015)\end{array}$ \\
\hline$N$ & & 407,998 & & & 407,998 & \\
\hline Married & $\begin{array}{c}0.003 \\
(0.009)\end{array}$ & $\begin{array}{c}0.002 \\
(0.008)\end{array}$ & $\begin{array}{c}0.003 \\
(0.008)\end{array}$ & $\begin{array}{c}0.029 \\
(0.026)\end{array}$ & $\begin{array}{c}0.028 \\
(0.025)\end{array}$ & $\begin{array}{c}0.034 \\
(0.025)\end{array}$ \\
\hline$N$ & & 236,265 & & & 236,265 & \\
\hline Age at First Birth & $\begin{array}{c}0.016 \\
(0.074)\end{array}$ & $\begin{array}{c}0.010 \\
(0.080)\end{array}$ & $\begin{array}{c}0.003 \\
(0.069)\end{array}$ & $\begin{array}{l}-0.063 \\
(0.209)\end{array}$ & $\begin{array}{l}-0.022 \\
(0.224)\end{array}$ & $\begin{array}{l}-0.066 \\
(0.192)\end{array}$ \\
\hline$N$ & & 609,278 & & & 609,278 & \\
\hline Age Gap in Marriage & $\begin{array}{c}0.011 \\
(0.072)\end{array}$ & $\begin{array}{c}0.015 \\
(0.071)\end{array}$ & $\begin{array}{c}0.023 \\
(0.074)\end{array}$ & $\begin{array}{c}0.303 \\
(0.291)\end{array}$ & $\begin{array}{c}0.267 \\
(0.285)\end{array}$ & $\begin{array}{c}0.284 \\
(0.292)\end{array}$ \\
\hline$N$ & & 127,781 & & & 127,781 & \\
\hline SEA FE & $\checkmark$ & $\checkmark$ & $\checkmark$ & $\checkmark$ & $\checkmark$ & $\checkmark$ \\
\hline $\begin{array}{l}\text { Exogenous Controls } \\
\text { Endogenous Controls }\end{array}$ & & $\checkmark$ & $\begin{array}{l}\checkmark \\
\checkmark\end{array}$ & & $\checkmark$ & $\begin{array}{l}\checkmark \\
\checkmark\end{array}$ \\
\hline
\end{tabular}

Notes: Each estimate is from a separate regression of pooled micro data from the 1940 and 1950 censuses. Each outcome variable is regressed on the World War II casualty rate interacted with a 1950 year indicator variable. All samples exclude individuals living in institutional group quarters. The sample for the dependent variables "Employed" and "Weeks Worked" is restricted to women in their childbearing age (between 15 and 44). For the "Employed with Child" variable, we further restrict the sample to only include women with at least one child. The sample for "Individual Income" is restricted to both males and females working for at least 35 hours per week between the age of 15 and 65. For the "Household Income" outcome, we consider individual income for single individuals and the average partners' income in each household for couples. We exclude farmers, self-employed and unpaid family workers for individual and household income. Top-coded values are imputed as 1.5 times the censored value for individual and household income. The variable "Married" equals one for women of childbearing age (between 15 and 44 years old)who got married in the last 10 years and zero for women who never got married. "Age of First Birth" is computed by subtracting the age of the eldest child from the mother's age. We restrict the sample to the "Age of First Birth" values between 15 and 45 to account for measurement errors. The variable "Age Gap in Marriage" is computed for married women as the difference between their partner's age and their own age. In the binary regressions 4 columns 1-3), "Casualty Rate" is a dummy that takes the value of one for high casualty rate counties and zero for low casualty rate counties. In the continuous regressions (columns 4-6), "Casualty Rate" is a continuous variable. Exogenous controls include the age (except for the "Age at First Birth"), race 
Table 6: Impact of World War II Casualties on Women's Economic Outcomes by Age Categories: Continuous Regressions

\begin{tabular}{|c|c|c|c|c|c|}
\hline & $\begin{array}{l}\text { Females } \\
15 \text { to } 24\end{array}$ & $\begin{array}{l}\text { Females } \\
25 \text { to } 34\end{array}$ & $\begin{array}{l}\text { Females } \\
35 \text { to } 44\end{array}$ & $\begin{array}{l}\text { Females } \\
45 \text { to } 54\end{array}$ & $\begin{array}{l}\text { Females } \\
55 \text { to } 65\end{array}$ \\
\hline Dependent Variables & $(1)$ & $(2)$ & $(3)$ & $(4)$ & $(5)$ \\
\hline Children Under Age of 5 & $\begin{array}{l}-0.055 \\
(0.030)\end{array}$ & $\begin{array}{c}-0.081 \\
(0.026)\end{array}$ & $\begin{array}{c}-0.052 \\
(0.021)\end{array}$ & $\begin{array}{c}-0.001 \\
(0.008)\end{array}$ & \\
\hline$N$ & 266,102 & 254,399 & 222,323 & 162,182 & \\
\hline Having a Child & $\begin{array}{c}-0.008 \\
(0.016)\end{array}$ & $\begin{array}{c}-0.026 \\
(0.016)\end{array}$ & $\begin{array}{c}-0.014 \\
(0.017)\end{array}$ & & \\
\hline$N$ & 266,102 & 254,399 & 222,323 & & \\
\hline Employed & $\begin{array}{c}0.078 \\
(0.018)\end{array}$ & $\begin{array}{c}0.037 \\
(0.022)\end{array}$ & $\begin{array}{c}0.037 \\
(0.017)\end{array}$ & $\begin{array}{c}0.064 \\
(0.026)\end{array}$ & $\begin{array}{c}0.024 \\
(0.021)\end{array}$ \\
\hline$N$ & 266,102 & 254,399 & 222,323 & 162,182 & 118,371 \\
\hline Weeks Worked & $\begin{array}{c}5.298 \\
(0.987)\end{array}$ & $\begin{array}{c}6.330 \\
(1.105)\end{array}$ & $\begin{array}{c}6.410 \\
(0.921)\end{array}$ & $\begin{array}{c}6.676 \\
(1.160)\end{array}$ & $\begin{array}{c}2.735 \\
(1.134)\end{array}$ \\
\hline$N$ & 266,102 & 254,399 & 222,323 & 162,182 & 118,371 \\
\hline Married & $\begin{array}{c}0.033 \\
(0.028)\end{array}$ & $\begin{array}{l}-0.011 \\
(0.027)\end{array}$ & $\begin{array}{l}-0.049 \\
(0.088)\end{array}$ & $\begin{array}{l}-0.107 \\
(0.109)\end{array}$ & $\begin{array}{c}0.034 \\
(0.083)\end{array}$ \\
\hline$N$ & 209,449 & 92,140 & 29,189 & 14,983 & 10,214 \\
\hline Age at First Birth & $\begin{array}{c}0.319 \\
(0.115)\end{array}$ & $\begin{array}{c}0.117 \\
(0.184)\end{array}$ & $\begin{array}{l}-0.042 \\
(0.208)\end{array}$ & & \\
\hline$N$ & 56,326 & 174,204 & 167,977 & & \\
\hline Age Gap in Marriage & $\begin{array}{c}0.011 \\
(0.479)\end{array}$ & $\begin{array}{c}-0.283 \\
(0.427)\end{array}$ & $\begin{array}{l}-0.041 \\
(0.613)\end{array}$ & $\begin{array}{c}0.226 \\
(0.642)\end{array}$ & $\begin{array}{c}-0.055 \\
(0.667)\end{array}$ \\
\hline$N$ & 16,412 & 37,332 & 30,674 & 22,188 & 15,038 \\
\hline SEA FE & $\checkmark$ & $\checkmark$ & $\checkmark$ & $\checkmark$ & $\checkmark$ \\
\hline Exogenous Controls & $\checkmark$ & $\checkmark$ & $\checkmark$ & $\checkmark$ & $\checkmark$ \\
\hline
\end{tabular}

Notes: Each outcome variable is regressed on the World War II casualty rate interacted with a 1950 year indicator variable. The casualty rate variable is considered as continuous in all the regressions (continuous regressions). The outcome "Children Under Age of 5 " indicates the number of own children age 4 and under residing with each individual. The binary variable "Having a Child" takes the value of one for women having at least one child (based on the number of children ever born to each woman). The sample for "Children Under Age of 5", "Having a Child", "Employed", and "Weeks Worked" includes the original sample of women based on their age category. For the "Married" outcome, we keep the sample of women who are married (treated) or single (comparison group) and exclude those who were divorced or widowed. For the "Age at First Birth", we adjust for measurement errors and remove observations for which the calculated age at first birth is lower than 15 or larger than 45. We restrict the sample to married women only for the regression on the "Age Gap in Marriage". See notes of Table 5 for additional details. Exogenous controls include race and ethnicity. SEA fixed effects are included for all regressions. Census person weights are used in all calculations. Standard errors in parenthesis are clustered at the SEA-level. 
Table 7: Impact of World War II Casualties on Children's Quality

\begin{tabular}{|c|c|c|c|c|c|c|}
\hline & \multicolumn{4}{|c|}{$\begin{array}{c}\text { Dependent Variable: \% of Live Births } \\
\text { Attended Physicians at Hospital }\end{array}$} & \multirow{2}{*}{\multicolumn{2}{|c|}{$\begin{array}{c}\text { Dependent Variable: } \\
\text { Log of Infant Mortalit } \\
1940-1960\end{array}$}} \\
\hline & \multicolumn{2}{|c|}{$1940-1950$} & \multicolumn{2}{|c|}{ 1940-1959 } & & \\
\hline & $\begin{array}{l}\text { Binary } \\
(1)\end{array}$ & $\begin{array}{c}\text { Cont. } \\
(2)\end{array}$ & $\begin{array}{l}\text { Binary } \\
\quad(3)\end{array}$ & $\begin{array}{l}\text { Cont. } \\
(4)\end{array}$ & $\begin{array}{c}\text { Binary } \\
(5)\end{array}$ & $\begin{array}{l}\text { Cont. } \\
(6)\end{array}$ \\
\hline After War & $\begin{array}{c}39.66 \\
(0.456)\end{array}$ & $\begin{array}{c}35.60 \\
(1.653)\end{array}$ & $\begin{array}{l}52.65 \\
(0.570)\end{array}$ & $\begin{array}{c}49.75 \\
(1.330)\end{array}$ & $\begin{array}{l}-0.372 \\
(0.022)\end{array}$ & $\begin{array}{l}-0.186 \\
(0.066)\end{array}$ \\
\hline $\begin{array}{l}\text { Casualty Rate } \times \\
\text { After War }\end{array}$ & $\begin{array}{c}3.010 \\
(0.667)\end{array}$ & $\begin{array}{c}5.417 \\
(1.630)\end{array}$ & $\begin{array}{c}0.761 \\
(0.813)\end{array}$ & $\begin{array}{c}3.238 \\
(1.263)\end{array}$ & $\begin{array}{l}-0.118 \\
(0.035)\end{array}$ & $\begin{array}{l}-0.244 \\
(0.068)\end{array}$ \\
\hline Female Population & $\checkmark$ & $\checkmark$ & $\checkmark$ & $\checkmark$ & $\checkmark$ & $\checkmark$ \\
\hline County FE & $\checkmark$ & $\checkmark$ & $\checkmark$ & $\checkmark$ & $\checkmark$ & $\checkmark$ \\
\hline \# of Counties & 3,069 & 3,069 & 3,066 & 3,066 & 1,564 & 1,564 \\
\hline Observations & 6,138 & 6,138 & 6,132 & 6,132 & 3,128 & 3,128 \\
\hline R-Squared & 0.841 & 0.842 & 0.862 & 0.862 & 0.535 & 0.540 \\
\hline
\end{tabular}

Notes: The dependent variable in columns 1 to 4 is computed as the number of live births attended by a physician at the hospital divided by the total number of live births by place of residence multiplied by 100. In columns 5 and 6 , the dependent variable is the natural log of infant mortality (under one) by place of occurrence. In the binary regressions (columns 1, 3 and 5), "Casualty Rate" is a dummy that takes the value of one for high casualty rate counties and zero for low casualty rate counties. In the continuous regressions (columns 2, 4 and 6), "Casualty Rate" is a continuous variable expressed as the number of casualties per 100 men. "After War" is a dummy that takes the value of one in 1950, 1959 or 1960 . County fixed effects and the natural log of female population are included in all regressions. Standard errors in parenthesis are clustered at the county-level. See notes of Table 3 for sample details. 